Article

\title{
Process Analysis of Main Organic Compounds Dissolved in Aqueous Phase by Hydrothermal Processing of Açaí (Euterpe oleraceae, Mart.) Seeds: Influence of Process Temperature, Biomass-to-Water Ratio, and Production Scales
}

\author{
Conceição de Maria Sales da Silva ${ }^{1}$, Douglas Alberto Rocha de Castro ${ }^{1}{ }^{(D)}$, Marcelo Costa Santos ${ }^{1}$, \\ Hélio da Silva Almeida ${ }^{1,2}$, Maja Schultze ${ }^{3}$, Ulf Lüder ${ }^{4}$, Thomas Hoffmann ${ }^{3}$ and Nélio Teixeira Machado ${ }^{1,2,3, * \mathbb{B}}$
}

1 Graduate Program of Natural Resources Engineering of Amazon, Rua Corrêa N ${ }^{\circ}$, Campus Profissional-UFPA, Belém 66075-110, Pará, Brazil; concisales@ufpa.br (C.d.M.S.d.S.); douglascastro87@hotmail.com (D.A.R.d.C.); marceloenqui@yahoo.com (M.C.S.); helioalmeida@ufpa.br (H.d.S.A.)

2 Faculty of Sanitary and Environmental Engineering, Rua Corrêa N ${ }^{\circ}$ 1, Campus Profissional-UFPA, Belém 66075-900, Pará, Brazil

3 Leibnitz-Institüt für Agrartechnik Potsdam-Bornin e.V, Department of Postharvest Technology, Max-Eyth-Alee 100, 14469 Potsdam, Germany; mschultze@atb-potsdam.de (M.S.);

check for updates

Citation: da Silva, C.d.M.S.; de Castro, D.A.R.; Santos, M.C.; Almeida, H.d.S.; Schultze, M.; Lüder, U.; Hoffmann, T.; Machado, N.T. Process Analysis of Main Organic Compounds Dissolved in Aqueous Phase by Hydrothermal Processing of Açaí (Euterpe oleraceae, Mart.) Seeds: Influence of Process Temperature, Biomass-to-Water Ratio, and Production Scales. Energies 2021, 14, 5608. https://doi.org/10.3390/ en14185608

Academic Editors: Andrea Di Carlo and Elisa Savuto

Received: 10 June 2021

Accepted: 25 July 2021

Published: 7 September 2021

Publisher's Note: MDPI stays neutral with regard to jurisdictional claims in published maps and institutional affiliations.

Copyright: (c) 2021 by the authors. Licensee MDPI, Basel, Switzerland. This article is an open access article distributed under the terms and conditions of the Creative Commons Attribution (CC BY) license (https:// creativecommons.org/licenses/by/ $4.0 /)$. THoffmann@atb-potsdam.de (T.H.)

4 SunCoal Industries GmbH, Rudolf-Diesel-Straße 15, 14974 Ludwigsfelde, Germany; info@suncoal.com

* Correspondence: machado@ufpa.br; Tel.: +55-91-984620325

Abstract: This work aims to systematically investigate the influence of process temperature, biomassto-water ratio, and production scales (laboratory and pilot) on the chemical composition of aqueous and gaseous phases and mass production of chemicals by hydrothermal processing of Açaí (Euterpe oleraceae, Mart.) seeds. The hydrothermal carbonization was carried out at $175,200,225$, and $250{ }^{\circ} \mathrm{C}$ at $2{ }^{\circ} \mathrm{C} / \mathrm{min}$ and a biomass-to-water ratio of $1: 10$; at $250{ }^{\circ} \mathrm{C}$ at $2{ }^{\circ} \mathrm{C} / \mathrm{min}$ and biomass-to-water ratios of 1:10, 1:15, and $1: 20$ in technical scale; and at 200,225 , and $250{ }^{\circ} \mathrm{C}$ at $2{ }^{\circ} \mathrm{C} / \mathrm{min}$ and a biomass-to-water ratio of 1:10 in laboratory scale. The elemental composition $(\mathrm{C}, \mathrm{H}, \mathrm{N}, \mathrm{S})$ in the solid phase was determined to compute the HHV. The chemical composition of the aqueous phase was determined by GC and HPLC and the volumetric composition of the gaseous phase using an infrared gas analyzer. For the experiments in the pilot test scale with a constant biomass-to-water ratio of 1:10, the yields of solid, liquid, and gaseous phases varied between 53.39 and 37.01\% (wt.), 46.61 and 59.19\% (wt.), and 0.00 and $3.80 \%$ (wt.), respectively. The yield of solids shows a smooth exponential decay with temperature, while that of liquid and gaseous phases showed a smooth growth. By varying the biomass-to-water ratios, the yields of solid, liquid, and gaseous reaction products varied between 53.39 and $32.09 \%$ (wt.), 46.61 and $67.28 \%$ (wt.), and 0.00 and $0.634 \%$ (wt.), respectively. The yield of solids decreased exponentially with increasing water-to-biomass ratio, and that of the liquid phase increased in a sigmoid fashion. For a constant biomass-to-water ratio, the concentrations of furfural and $\mathrm{HMF}$ decreased drastically with increasing temperature, reaching a minimum at $250{ }^{\circ} \mathrm{C}$, while that of phenols increased. In addition, the concentrations of $\mathrm{CH}_{3} \mathrm{COOH}$ and total carboxylic acids increased, reaching a maximum concentration at $250{ }^{\circ} \mathrm{C}$. For constant process temperature, the concentrations of aromatics varied smoothly with temperature. The concentrations of furfural, $\mathrm{HMF}$, and catechol decreased with temperature, while that of phenols increased. The concentrations of $\mathrm{CH}_{3} \mathrm{COOH}$ and total carboxylic acids decreased exponentially with temperature. Finally, for the experiments with varying water-to-biomass ratios, the productions of chemicals (furfural, HMF, phenols, cathecol, and acetic acid) in the aqueous phase is highly dependent on the biomass-towater ratio. For the experiments at the laboratory scale with a constant biomass-to-water ratio of 1:10, the yields of solids ranged between 55.9 and $51.1 \%$ (wt.), showing not only a linear decay with temperature but also a lower degradation grade. The chemical composition of main organic compounds (furfural, HMF, phenols, catechol, and acetic acid) dissolved in the aqueous phase in laboratory-scale study showed the same behavior as those obtained in the pilot-scale study. 
Keywords: Açaí seeds; hydrothermal carbonization; hot compressed water; process analysis; HMF; furfural; acetic acid; mass production

\section{Introduction}

Açaí (Euterpe oleracea Mart.) is a palm native to the Brazilian Amazon [1]. It has an abundant occurrence in the Amazon estuary floodplains [2,3]. The Açaí fruits in nature have great economic importance for the agroindustry, as well as extractive activities of rural communities of the Brazilian Amazonian state of Pará [4]. The fruit is a small, dark-purple, berry-like fruit, almost spherical, weighing between 2.6 to $3.0 \mathrm{~g}$ [5]. The fruit has a diameter around 10.0 and $20.0 \mathrm{~mm}$ [5], containing a large core seed/kernel that occupies between 85 and $95 \%$ (vol./vol.) of its volume $[3,6]$.

When the pulp and skin are processed/extracted with warm water to produce a thick, purple-colored juice [3,6], a waste is generated [7-11], namely the Açaí seeds, a rich lignin-cellulosic residue with great potential for energetic use $[8,9,12]$. In the crop years 2016-2017, around 1200-1274 million tons of Açaí fruits were produced in Brazil;-the state of Pará is the main producer (94\%), generating large amounts of solid residues consisting of seeds and fibers [4-9].

The residue of Açaí fruit (seeds + fibers) processing has a fibrous outer layer, containing $46.51 \%$ (wt.) cellulose and $30.31 \%$ (wt.) lignin [11]; this residue (seeds + fibers) is composed of $36.13 \%$ (wt.) cellulose, $47.92 \%$ (wt.) lignin, $1.57 \%$ (wt.) ash, and $16.64 \%$ (wt.) extractives [11], representing an important renewable biomass source for energetic applications $[8,9,12]$.

The thermo-chemical transformation of lignin-cellulose-rich biomass with $\mathrm{H}_{2} \mathrm{O}$ in the sub-critical or supercritical state is a promising technique, and the literature reports several studies on the subject [13-49]. Li et al. [13] applied statistical methods to investigate the role of process conditions (temperature, reaction time, biomass-to-water ratio) and chemical raw material characteristics on the physical-chemical properties of hydrothermal carbonization products (solid, liquid, and gas). In addition, Li et al. [13] reported that the most commonly cited hydrothermal carbonization product parameter was solid (hydro-char) yield (71\%), while little attention has been paid to carbon-related information on the liquid and gaseous phases $(<18 \%)$, which includes the analysis of chemical composition.

In fact, only a few studies systematically investigated the composition of the main chemical compounds, such as aromatic-ring compounds (furfural, HMF, phenols, cresols, catechol, guaiacol, etc.) [14,18,39-41], carboxylic acids $\left(\mathrm{HCOOH}, \mathrm{CH}_{3} \mathrm{COOH}, \mathrm{CH}_{3} \mathrm{CH}_{2} \mathrm{COOH}\right.$, $\mathrm{CH}_{3} \mathrm{CH}(\mathrm{OH}) \mathrm{COOH}, \mathrm{CH}_{3} \mathrm{C}(\mathrm{O}) \mathrm{CH}_{2} \mathrm{CH}_{2} \mathrm{COOH}$, etc.) $[14,18,39,40,43]$, alcohols $\left(\mathrm{CH}_{3} \mathrm{OH}\right.$, $\mathrm{CH}_{3} \mathrm{CH}_{2} \mathrm{OH}$ ) [14], sugars (glucose, xylose, galactose, fructose, sucrose, mannosan, levoglucosan, etc.) [18,40,43], and BTEX (benzene, toluene, xylenes, and ethylbenzene) [41]. In these studies, the above compounds were dissolved in the process water by hydrothermal carbonization of biomass, including the hydrothermal processing of corn stover [14,18]; Tahoe mix, pinyon/juniper, loblolly pine wood, sugar bagasse, and rice hulls [18]; wheat straw, wheat straw digestate, poplar, garapa, massaranduba, pine wood, $\alpha$-Cellulose, and D-(+)-xylose [39]; wheat straw, poplar, and $\alpha$-Cellulose [40]; wheat straw, wheat straw digestate, poplar, garapa, massaranduba, and pine wood [41]; Tahoe mix [43]; and biodegassed pellets [49]. Recently, Poerschmann et al. [44] investigated the distribution of medium molar mass compounds dissolved in process water by hydrothermal carbonization of glucose, fructose, and xylose by GC-MS and IC, identifying more than 50 compounds, the most abundant being carboxylic acids (formic, acetic, glycolic, lactic, and levulinic acids) and aromatic-ring compounds (furfural, 5-(Hydroxymethyl)-2-furfural).

Another process parameter affecting the physical-chemical properties of hydrothermal carbonization products (solid, liquid, and gas) is the water-to-biomass ratio [19,25-30]. In recent years only a few studies have investigated the influence of the water-to-biomass ratio from the hydrothermal processing of biomass, including tomato-peel-waste [26], olive 
stone [27], microalgae [28], sawdust [29], banana peels [30], wood chips [25], and corn stalks [19], but no study has examined their influence consistently [13], particularly the composition of the main chemical compounds dissolved in the process water.

Açaí (Euterpe oleracea, Mart.) is the only fruit species whose seed's centesimal and elemental composition is completely different from wood biomass (e.g., poplar, garapa, massaranduba, Tahoe mix, pinyon/juniper, loblolly pine, and pine wood) [18,39-41,43], agriculture residues of cereal grains (corn stover, corn stalk, rice hulls, and wheat straw), or agriculture residues of sugar cane (sugar bagasse) [18]. Although hydrothermal treatment has been applied to enhance enzymatic hydrolysis of Açaí seeds in aqueous $\mathrm{H}_{2} \mathrm{SO}_{4}$ at $121{ }^{\circ} \mathrm{C}$ [47], no systematic study has investigated the influence of temperature, biomass-towater ratio, and production scales (laboratory and pilot) on the chemical composition of aqueous and gaseous phases, as well as on the mass production of chemicals by hydrothermal carbonization of Açaí seeds on a technical scale.

This work aims to investigate the influence of process temperature, biomass-to-water ratio, and production scales (laboratory and pilot) on the chemical composition of the main chemical compounds, such as aromatic-ring compounds, carboxylic acids, and alcohols, dissolved in process water, the gaseous phase composition, and mass production of chemicals by hydrothermal processing of Açaí (Euterpe oleracea, Mart.) seeds on a technical scale.

\section{Materials and Methods}

\subsection{Methodology}

The process flow sheet shown in Figure 1 summarizes the applied methodology, described in a logical sequence of ideas, chemical methods, and procedures, to analyze the chemical composition of main compounds in the liquid phase by HTC of Açaí seeds.

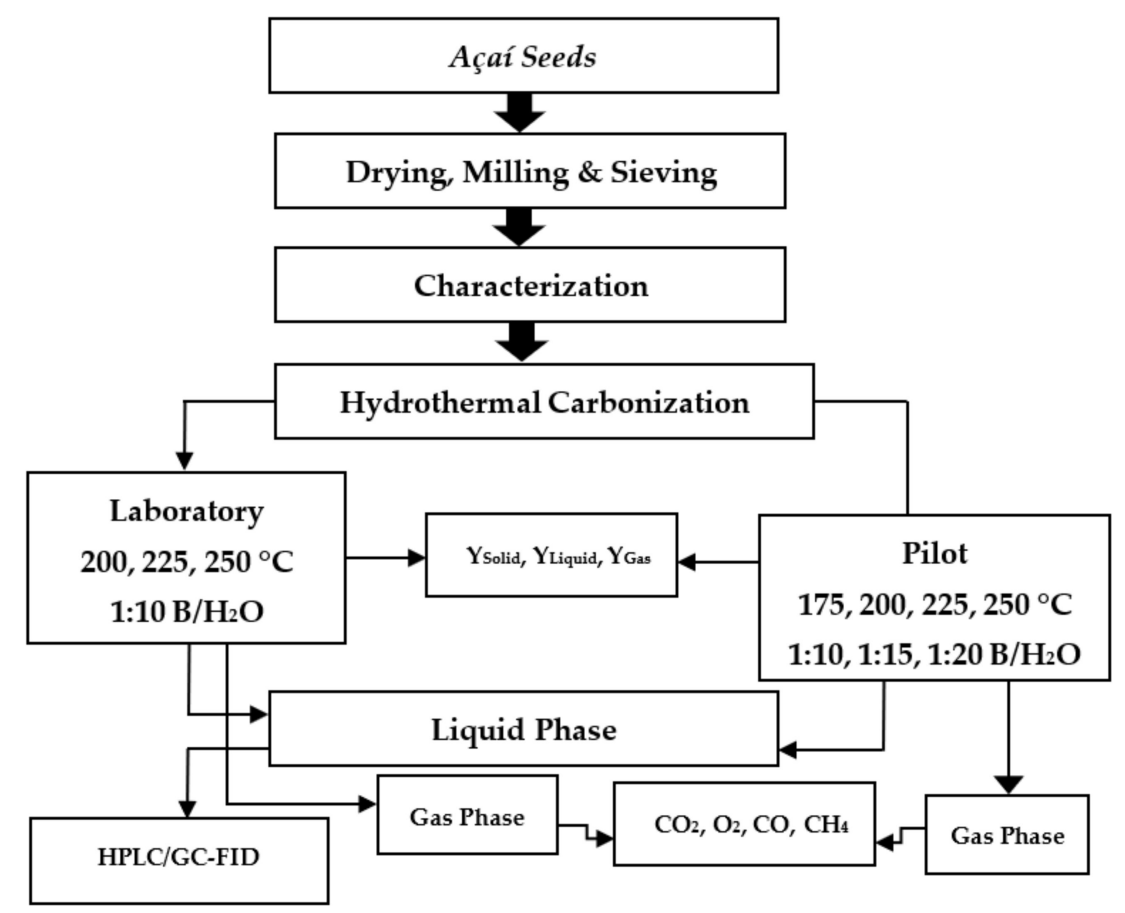

Figure 1. Process flow sheet for hydrothermal processing of Açaí (Euterpe oleracea, Mart.) seeds with hot compressed $\mathrm{H}_{2} \mathrm{O}$ in laboratory and pilot scales.

Initially, the Açaí seeds were collected. Afterward, they were subjected to pretreatments of drying, followed by milling and sieving. The HTC was carried out at laboratory and pilot scales to investigate the influence of temperature $\left(175,200,225,250^{\circ} \mathrm{C}\right)$ and biomass-to-water ratio (1:10, 1:15, 1:20) on the yields of hydro-char, $\mathrm{H}_{2} \mathrm{O}$, and gas, as well as on the chemical composition in the liquid phase. Finally, the influence of production scales on the composition of the main compounds (furfural, HMF, phenols, catechol, 
guaiacol, $\mathrm{HCOOH}$, etc.) in the liquid phase was investigated. The composition in the gas phase $\left(\mathrm{CH}_{4}, \mathrm{CO}_{2}, \mathrm{O}_{2}, \mathrm{CO}\right)$ was determined by infrared spectroscopy, and that of the liquid phase was determined by HPLC and GC-FID.

\subsection{Materials, Pre-Treatment, and Characterization of Açai Seeds in Nature}

The charges of Açaí seeds in nature obtained in a small Açaí store of in the city of BelémPará, Brazil [12]. The seeds were dried at $105^{\circ} \mathrm{C}$, ground using a knife cutting mill, and sieved using an 18 mesh sieve [12]. Afterward, the seeds underwent physical-chemistry characterization for moisture (AOAC 935.29), volatile matter (ASTM D 3175-07), ash (ASTM D 3174-04), fixed carbon (ASTM D6316-09), lipids (AOAC 963.15), proteins (AOAC 991.20) [12], and fibers according to the literature [50] and for insoluble lignin by the modified method of Klason [51]. The elemental composition (C, H, N, S) of Açaí seeds in the solid phase was also determined. Figure 2 shows the Açaí seeds after drying, milling, and sieving (seeds + fibers (a); comminuted seeds + fibers (b); and sieved seeds + fibers (c)). The HTC experiments were carried out with sieved seeds + fibers, as shown in Figure 2c.

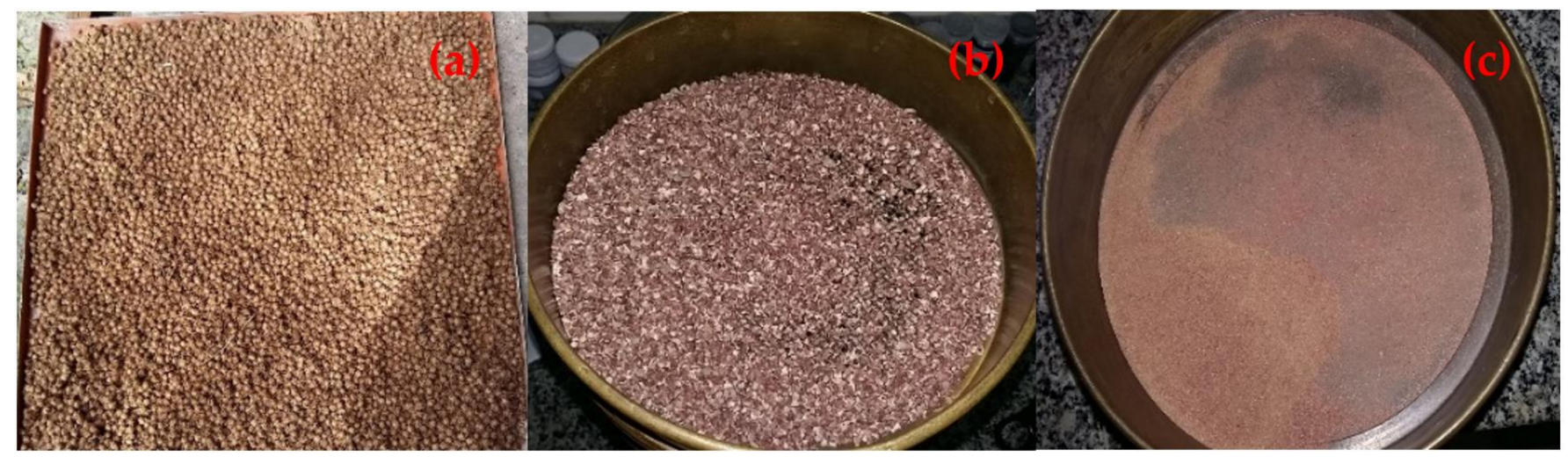

Figure 2. Material after drying, milling, and sieving process of Açaí seeds (seeds + fibers (a); comminuted seeds + fibers (b); and sieved seeds (c)).

\subsection{Experimental Apparatus and Procedures}

\subsubsection{Experimental Apparatus and Procedures in Pilot Scale}

Pilot-scale apparatus is illustrated in Figure 3, described in details elsewhere [14].

The hydrothermal processing of dried Açaí seeds was carried out with hot compressed water at $175,200,225$, and $250{ }^{\circ} \mathrm{C}$ for $240 \mathrm{~min}$ with a biomass-to-water ratio of 1:10 and at $250{ }^{\circ} \mathrm{C}$ for $240 \mathrm{~min}$ with biomass-to-water ratios of 1:10, 1:15, and 1:20, as described in detail elsewhere [14].

\subsubsection{Experimental Apparatus and Procedures in Laboratory Scale}

The laboratory-scale apparatus is illustrated in Figure 4. The laboratory-scale cylindrical stirred tank stainless steel reactor is $1.0 \mathrm{~L}$ (Parr, USA, Model: 4577), with internal diameters of $9.525 \mathrm{~cm}$ and $15.748 \mathrm{~cm}$ and a weight of $7.257 \mathrm{~kg}$. The reactor contains a mechanical agitation system with a stirrer motor of $\frac{1}{4} \mathrm{hp}, 1.81 \mathrm{Nm}$ torque, and 02 impellers $(\mathrm{ID}=5.08 \mathrm{~cm})$ with 6 blades, a ceramic movable heater of $2800 \mathrm{~W}$, a modular controller (Parr, Moline, IL, USA, Model: 4848), and 02 type J thermocouples inside a thermos well and operates at maximum conditions of $345 \mathrm{bar}$ and $500{ }^{\circ} \mathrm{C}$. The hydrothermal processing of dried Açaí seeds was carried out with hot compressed water at 200,225 , and $250{ }^{\circ} \mathrm{C}$ for $240 \mathrm{~min}$, with a biomass-to-water ratio of 1:10. Initially, the solid moisture was determined, and the mass of water was computed based on the dried solid. A mass of $73.50 \mathrm{~g}$ of solid with $25 \%$ (wt.) moisture was added to $532.82 \mathrm{~g}$ of distilled and deionized water and was introduced in the reactor. The operating temperatures $\left(200,225\right.$, and $250{ }^{\circ} \mathrm{C}$ ) set for a heating rate of $2.0^{\circ} \mathrm{C} / \mathrm{min}$. The reaction time was computed from the time the reactor reached the setpoint temperature $\left(\tau_{0}\right)$. Afterwards, the reactor was cooled until ambient temperature. The reaction products, including a moist dewatered solid phase and 
a liquid phase, were determined gravimetrically. Then, the moist solid phase was dried at $105^{\circ} \mathrm{C}$ for $24 \mathrm{~h}$. The volume of the gas and its composition were determined, as described elsewhere [14]. The samples of moist dewatered solid, liquid, and dried solid phases were stored for physicochemical analysis.

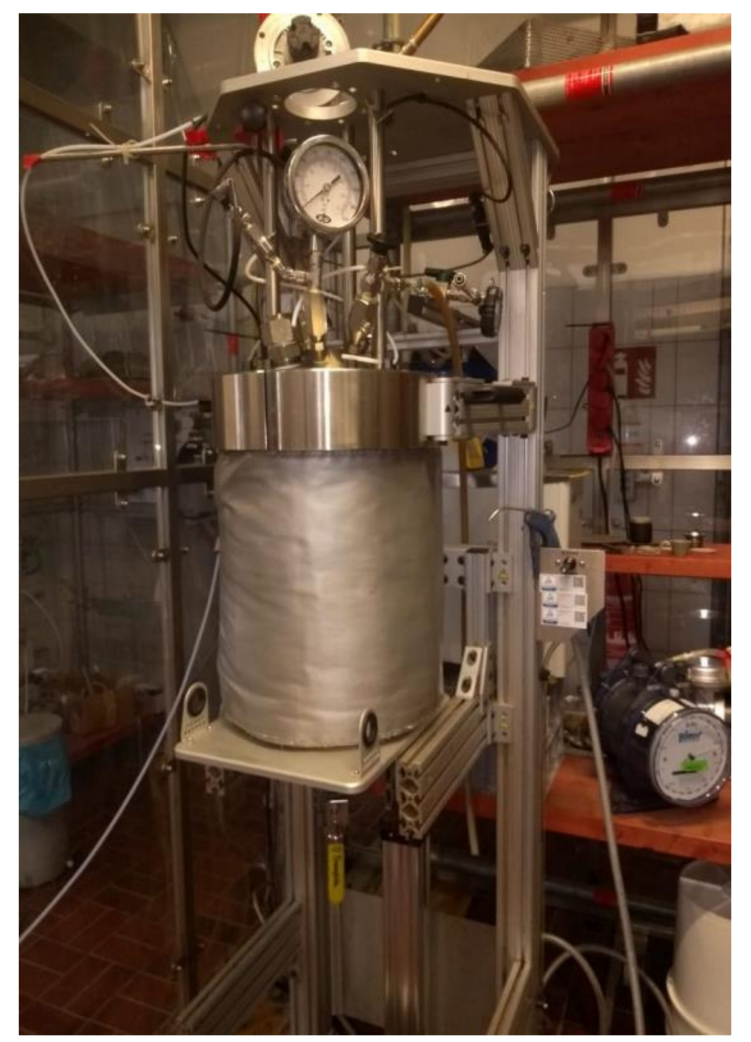

Figure 3. Pilot-scale stirred tank stainless steel reactor of 18.92 P L (Parr, USA, Model: 4555).

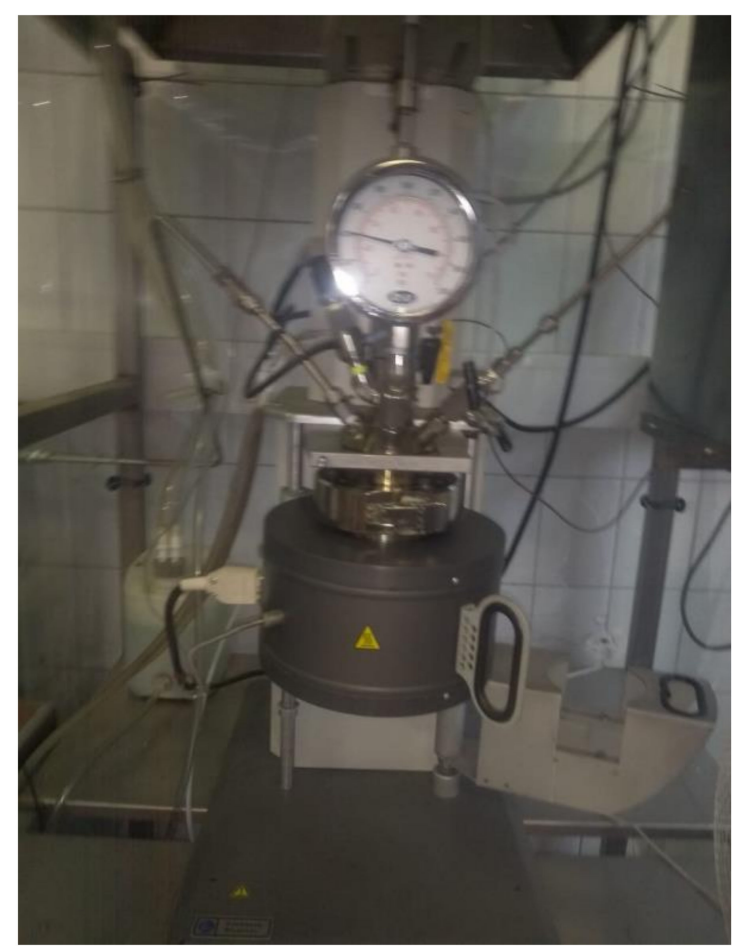

Figure 4. Pilot-scale stirred tank stainless steel reactor of 1.0 L (Parr, Moline, IL, USA, Model: 4577). 


\subsection{Compositional Analysis of Reaction Products}

\subsubsection{Aqueous Phase}

The chemical analysis of volatile low-chain length carboxylic acids ( $\mathrm{R}-\mathrm{COOH}$, with $\left.\mathrm{R}_{1}=\mathrm{CH}_{3}, \mathrm{R}_{2}=\mathrm{C}_{2} \mathrm{H}_{5}, \mathrm{R}_{3}=\mathrm{C}_{3} \mathrm{H}_{7}, \mathrm{R}_{4}=\mathrm{C}_{4} \mathrm{H}_{9}\right)$ and alcohols ( $\mathrm{R}-\mathrm{OH}$, with $\mathrm{R}_{1}=\mathrm{CH}_{3}, \mathrm{R}_{2}=\mathrm{C}_{2} \mathrm{H}_{5}$, $\mathrm{R}_{3}=\mathrm{C}_{3} \mathrm{H}_{8}$ ), as well as selective cellulose/hemicellulose-derived compounds, was done by hydrothermal processing of biomass and then identified by GC while the selective cellulose/hemicellulose-derived phenolic (phenol, cresol, catechol, and guaiacol) and aldehyde (furfural, HMF) compounds were identified by HPLC. The equipment specifications (GC-FID, HPLC), and operating conditions, including the GC-FID temperature program, as well as HPLC procedures, are described in detail elsewhere [14].

\subsubsection{Gaseous Phase}

The volume of gas, degassed at $25^{\circ} \mathrm{C}$ and 1.0 atmosphere, was measured with a gas flow meter, while an infrared gas analyzer was used to determine the volumetric composition of gaseous products [14]. The equipment's specifications and procedures are described in detail elsewhere [14].

\subsection{Steady-State Material Balance by Hydrothermal Carbonization}

The yields of reaction products (solid, liquid, and gaseous phases) were determined by applying the mass conservation principle within the stirred tank reactor, operating in batch mode in a closed thermodynamic system, and the equations are described in detail elsewhere [14].

\section{Results}

\subsection{Hydrothermal Processing of Açaí Seeds}

3.1.1. Material Balances, Operating Conditions, and Yields of Reaction Products Influence of Temperature on the Yields of Reaction Products

The material balances, operating conditions, and yields of reaction products by hydrothermal processing of Açaí seeds in nature at $175,200,225$, and $250{ }^{\circ} \mathrm{C}$, with an increase of $2{ }^{\circ} \mathrm{C} / \mathrm{min}$ for $240 \mathrm{~min}$, and a biomass-to-water ratio of 1:10, at a pilot scale, are summarized in Table 1.

Figure 5 shows the effect of temperature on the yields of reaction products by hydrothermal processing of Açaí seeds in nature with hot, compressed $\mathrm{H}_{2} \mathrm{O}$ heated by $2{ }^{\circ} \mathrm{C} / \mathrm{min}$ to $175,200,225,250{ }^{\circ} \mathrm{C}$ for $240 \mathrm{~min}$ with a biomass-to-water ratio of $1: 10$. The exponential function applied to regress the yields of reaction products correlated well with the experimental data for both the solid and liquid phases, with $\mathrm{r}^{2}$ (R-Squared) between 0.996 and 0.996 . The yield of dry solids shows a smooth first-order exponential decay behavior, while that of the liquid and gaseous phases shows a smooth first-order exponential growth. At $175^{\circ} \mathrm{C}$, hydrothermal carbonization takes place, as the main reaction product is a solid [15]. At $200{ }^{\circ} \mathrm{C}$ hydrothermal liquefaction occurs, and the main reaction products are liquids [15]. The hydro-char yields were similar to those reported in the literature for rye straw [16], eucalyptus leaves [17], corn stover [14], sugarcane bagasse [18], and corn stalk [19]. 
Table 1. Mass balances, processes, operating conditions, and yields of dry solid, liquid, and gaseous products by hydrothermal processing of Açaí seeds with hot compressed $\mathrm{H}_{2} \mathrm{O}$ at $175,200,225,250{ }^{\circ} \mathrm{C}$, $2{ }^{\circ} \mathrm{C} / \mathrm{min}, 240 \mathrm{~min}$, and biomass-to-water ratio of $1: 10$, at a pilot scale.

\begin{tabular}{|c|c|c|c|c|}
\hline \multirow[b]{2}{*}{ Process Parameters } & \multicolumn{3}{|c|}{ Temperature $\left({ }^{\circ} \mathrm{C}\right)$} & \multirow[b]{2}{*}{250} \\
\hline & 175 & 200 & 225 & \\
\hline Mass of Açaí Seeds [g] & 300.00 & 299.82 & 299.98 & 300.16 \\
\hline Mass of $\mathrm{H}_{2} \mathrm{O}[\mathrm{g}]$ & 2997.60 & 3000.20 & 3001.30 & 2999.90 \\
\hline Mechanical Stirrer Speed [rpm] & 90 & 90 & 90 & 90 \\
\hline Initial Temperature $\left[{ }^{\circ} \mathrm{C}\right]$ & 30 & 30 & 30 & 30 \\
\hline Heating Rate $\left[{ }^{\circ} \mathrm{C} / \mathrm{min}\right]$ & 2 & 2 & 2 & 2 \\
\hline Process Time [min] & 240 & 240 & 240 & 240 \\
\hline Mass of Slurry $[\mathrm{g}]$ & 3252.20 & 3240.20 & 3216.50 & 3167.40 \\
\hline Volume of Gas [mL], $\mathrm{T}=25^{\circ} \mathrm{C}, \mathrm{P}=1 \mathrm{~atm}$ & 0 & 5290 & 5590 & 7470 \\
\hline Mass of Gas $[\mathrm{g}]$ & 0 & 7.564 & 8.231 & 11.408 \\
\hline Process Loss (I) $[\mathrm{g}]$ & 45.40 & 59.82 & 84.78 & 132.66 \\
\hline Input Mass of Slurry (Pressing) [g] & 3252.20 & 3240.20 & 3216.50 & 3161.70 \\
\hline Process Loss (II) $[\mathrm{g}]$ & 0.00 & 0.00 & 0.00 & 5.70 \\
\hline Mass of Liquid Phase [g] & 2638.53 & 2615.56 & 2637.97 & 2556.96 \\
\hline Mass of Moist Hydro-char [g] & 588.10 & 587.37 & 557.61 & 591.29 \\
\hline Process Loss (III) [g] & 25.57 & 37.27 & 20.92 & 13.41 \\
\hline $\begin{array}{l}\text { Mass of Dry Hydro-char [g] } \\
\text { (Mass of Liquid Phase }+\sum \text { Process }\end{array}$ & 160.16 & 118.53 & 113.052 & 111.092 \\
\hline $\begin{array}{l}\text { Loss + Mass of Moist Hydro-char - Mass } \\
\text { of Dry Hydro-char - Mass of Gas) [g] }\end{array}$ & 3137.44 & 3173.926 & 3179.997 & 3177.52 \\
\hline Process Loss (I + II + III) [g] & 70.97 & 97.09 & 105.70 & 151.77 \\
\hline Mass of Liquid ${ }_{\text {Reaction }}[\mathrm{g}]$ & 139.84 & 173.726 & 178.697 & 177.62 \\
\hline Yield of Hydro-char [wt.\%] & 53.39 & 39.534 & 37.686 & 37.011 \\
\hline Yield of Liquid Phase [wt.\%] & 46.61 & 57.943 & 59.570 & 59.188 \\
\hline Yield of Gas [wt.\%] & 0.000 & 2.523 & 2.744 & 3.801 \\
\hline
\end{tabular}

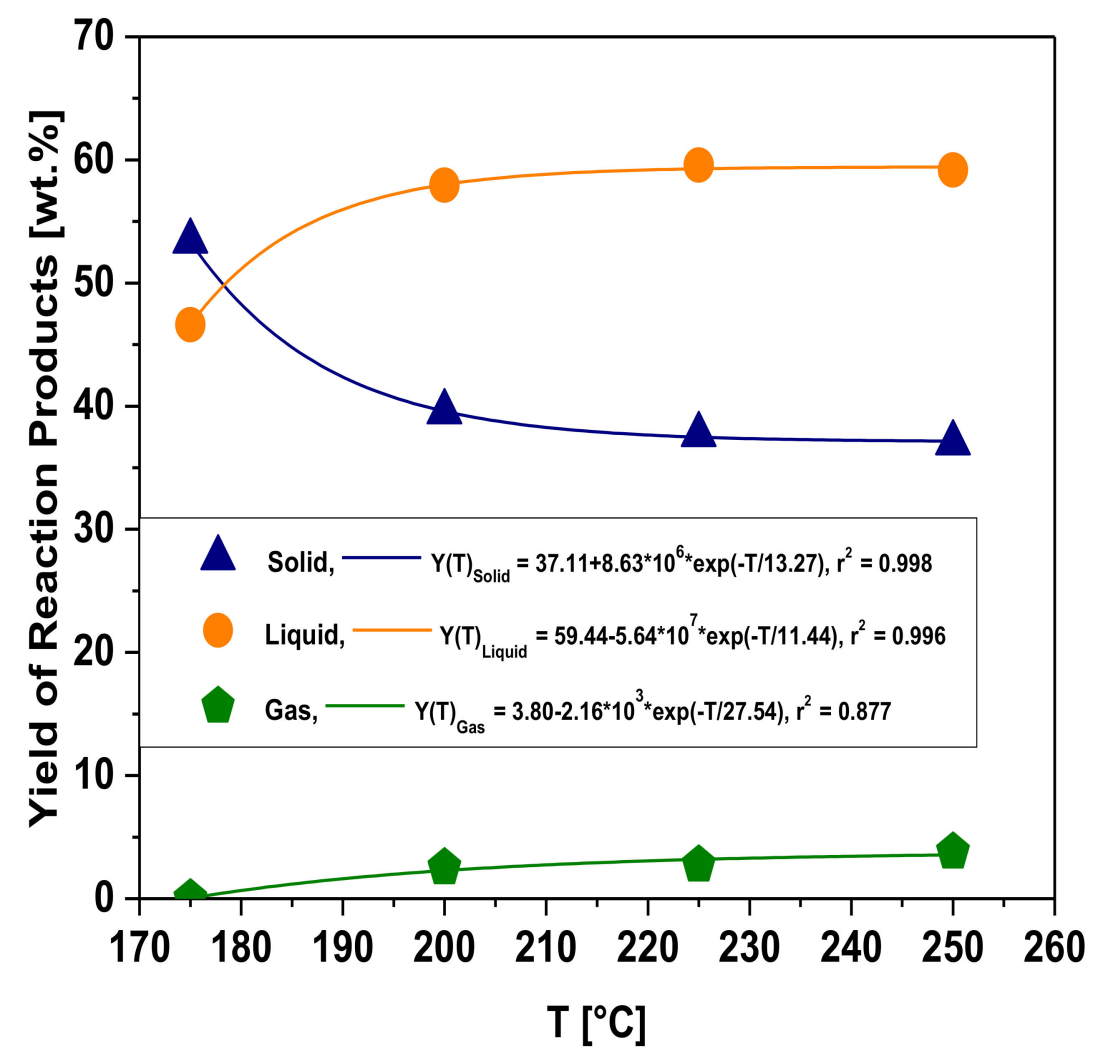

Figure 5. Effect of temperature on the yields of reaction products by hydrothermal processing of Açaí seeds in nature.

The centesimal composition of Açaí (Euterpe oleracea Mart.) seeds [12] was found to be $40.29 \%$ (wt.) cellulose, 5.5\% (wt.) hemi-cellulose, 4.0\% (wt.) lignin, 29.79\% fibers, as well as $6.25 \%$ (wt.) protein, $0.61 \%$ (wt.) lipid, 10.15\% (wt.) moisture, $0.5 \%$ (wt.) volatile matter, 
$0.83 \%$ (wt.) fixed carbon, and $0.15 \%$ (wt.) ash. The centesimal composition of Açaí fibers in nature is $41.37 \%$ (wt.) cellulose, $11.54 \%$ (wt.) hemi-cellulose, $40.25 \%$ (wt.) lignin, $1.96 \%$ ash, and $8.88 \%$ moisture, as reported by Tavares et al. [7].

Based on the facts that $61.25 \%$ (wt.) cellulose and $15 \%$ (wt.) lignin decompose at $200{ }^{\circ} \mathrm{C}$ over $24 \mathrm{~h}$ with a 1:10 biomass-to-water ratio (according to Falco et al. [16]), that $5.0 \%$ (wt.) lipids and $72 \%$ (wt.) proteins decompose at $350{ }^{\circ} \mathrm{C}$ over 90 min with a $1: 5.7$ biomass-to-water ratio (as reported by Teri et al. [20]), that hemicellulose degrades 65\% (wt.) by a severity factor between 4.5 and 5.0 (as reported by Borrero-López et al. [21]), and that approximately 50\% (wt.) cotton fibers decompose at $210{ }^{\circ} \mathrm{C}$ over $8.0 \mathrm{~h}$ with a $1: 41$ biomass-to-water ratio (as reported by Zhang et al. [22]), one may perform a centesimal mass balance to compute the approximate theoretical mass degradation of Açaí seeds at $200{ }^{\circ} \mathrm{C}, 2{ }^{\circ} \mathrm{C} / \mathrm{min}, 240 \mathrm{~min}$, and a biomass-to-water ratio of 1:10, using the following equation, computed in Table 2 . The $\mathrm{Y}_{\text {Hydro-char/Cellulose }}$ is computed by multiplying the percentage of cellulose in the centesimal composition of Açaí seeds by the fraction of non-degraded cellulose $\left(\mathrm{Y}_{\text {Hydro-char/Cellulose }}=40.29 \% \times(100-61.25) / 100=15.6124 \%\right)$, as summarized in Table 2.

$\mathrm{Y}_{\text {Hydro-char }}=\sum \mathrm{Y}_{\text {Hydro-char/Cellulose }}+\mathrm{Y}_{\text {Hydro-char/Lignin }}+\mathrm{Y}_{\text {Hydro-char } / \text { Hemi-Cellulose }}+\mathrm{Y}_{\text {Hydro-char } / \text { Proteins }}+\mathrm{Y}_{\text {Hydro-char } / \text { Lipids }}+\mathrm{Y}_{\text {Hydro-char/Fibers }}$

The yield of hydro-char computed using Equation (1) is very close to the experimental value of $39.534 \%$ (wt.), showing a deviation of $2.51 \%$, if the yield of $\mathrm{Y}_{\text {Hydro-char/Fibers }}$ is computed based on the decomposition of cellulose, lignin, and hemi-cellulose $\left(\mathrm{Y}_{\text {Hydro-char } / \text { Fibers }}=16.17 \%\right)$, and $5.68 \%$, if the yield of $\mathrm{Y}_{\text {Hydro-char/Fibers }}$ is computed based on the decomposition of fibers $\left(\mathrm{Y}_{\text {Hydro-char } / \text { Fibers }}=14.895 \%\right)$. In addition, the computed amount of Açaí seeds fibers (29.79\% (wt.)) degraded at $200{ }^{\circ} \mathrm{C}, 240 \mathrm{~min}$, and the biomass-to-water ratio of 1:10 was $16.17 \%$ (wt.), giving a degradation percentage of $54.28 \%$, very close to the results reported by Zhang et al. [22] who stated that approximately $50 \%$ (wt.) cotton fibers decompose at $210{ }^{\circ} \mathrm{C}$ over $8.0 \mathrm{~h}$ with a 1:41 biomass-to-water ratio.

Table 2. Computation of hydro-char yield. Centesimal composition of Açaí seeds and Açaí fibers from nature [7,12], decomposition cellulose and lignin [16], decomposition of lipids and proteins [20], decomposition of hemicellulose [21], decomposition of cotton fibers [22].

\begin{tabular}{|c|c|c|c|c|c|c|c|}
\hline \multirow[b]{2}{*}{$\begin{array}{l}\text { Centesimal } \\
\text { Composition }\end{array}$} & \multirow[b]{2}{*}{ [wt.\%] } & \multicolumn{6}{|c|}{ Decomposition } \\
\hline & & $\begin{array}{l}\text { Cellulose } \\
\text { [wt.\%] }\end{array}$ & $\begin{array}{l}\text { Lignin } \\
\text { [wt. \%] }\end{array}$ & $\begin{array}{l}\text { Hemi-Cellulose } \\
\text { [wt.\%] }\end{array}$ & $\begin{array}{l}\text { Proteins } \\
\text { [wt.\%] }\end{array}$ & $\begin{array}{l}\text { Lipids } \\
\text { [wt.\%] }\end{array}$ & $\begin{array}{l}\text { Fibers } \\
\text { [wt.\%] }\end{array}$ \\
\hline & & 61.25 & 15.00 & 65.00 & 72.00 & 5.00 & 50.00 \\
\hline Açaí Seeds [12] & & - & - & - & - & - & - \\
\hline Cellulose & 40.29 & 15.6124 & - & - & - & - & - \\
\hline Lignin & 4.00 & - & 3.40 & - & - & - & - \\
\hline Hemi-cellulose & 5.50 & - & - & 1.925 & & & - \\
\hline Proteins & 6.25 & - & - & - & 1.82 & & - \\
\hline Lipids & 0.61 & - & - & - & - & 0.5795 & - \\
\hline Fibers & 29.79 & - & - & - & - & - & 14.895 \\
\hline Moisture & 10.15 & - & - & - & - & - & - \\
\hline Volatile matter & 0.50 & - & - & - & - & - & - \\
\hline Fixed carbon & 0.83 & - & - & - & - & - & - \\
\hline Ash & 0.15 & - & - & - & - & - & - \\
\hline $\begin{array}{l}\text { Y }_{\text {Hydro-char/Seeds }} \\
\text { [wt.\%] }\end{array}$ & 37.287 & 15.6124 & 3.400 & 1.925 & 1.820 & 0.5795 & 14.895 \\
\hline Açaí Fibers [7] & & - & - & - & - & - & - \\
\hline Cellulose & 41.37 & 16.080 & - & - & - & - & - \\
\hline Lignin & 40.25 & - & 34.213 & - & - & - & - \\
\hline Hemi-cellulose & 11.54 & - & - & 4.039 & - & - & - \\
\hline Moisture & 8.88 & - & - & - & - & - & - \\
\hline Ash & 1.96 & - & - & - & - & - & - \\
\hline $\begin{array}{l}\mathbf{Y}_{\text {Hydro-char/Fibers }} \\
\text { [wt.\%] }\end{array}$ & 16.170 & 4.775 & 10.192 & 1.203 & - & - & - \\
\hline
\end{tabular}

By analyzing the thermal decomposition behavior of cellulose and lignin reported by Falco et al. [16], one observes that the decomposition of cellulose is almost constant 
between $200{ }^{\circ} \mathrm{C}$ and $240{ }^{\circ} \mathrm{C}(38.75 \rightarrow 37.00)$, showing that degradation/de-polymerization of cellulose is less intense [19], while lignin loses only $7.5 \%$ of its initial mass $(85 \% \rightarrow 77.5 \%)$, thus making it possible to explain the small differences for the solid phase yields between $200{ }^{\circ} \mathrm{C}$ and $250{ }^{\circ} \mathrm{C}$.

The material balances, operating conditions, and yields of reaction products by hydrothermal processing of Açaí seeds from nature at 200,225 , and $250{ }^{\circ} \mathrm{C}$ heated at $2{ }^{\circ} \mathrm{C} / \mathrm{min}$ over 240 min with a biomass-to-water ratio of 1:10, at laboratory scale, are summarized in Table 3.

Table 3. Mass balances, processes, operating conditions, and yields of solid, liquid, and gaseous products by hydrothermal processing of Açaí seeds with hot compressed $\mathrm{H}_{2} \mathrm{O}$ at $200,225,250{ }^{\circ} \mathrm{C}$, $2{ }^{\circ} \mathrm{C} / \mathrm{min}, 240 \mathrm{~min}$, and biomass-to-water ratio of $1: 10$, in laboratory scale.

\begin{tabular}{|c|c|c|c|}
\hline \multirow[b]{2}{*}{ Process Parameters } & \multicolumn{3}{|c|}{ Temperature $\left[{ }^{\circ} \mathrm{C}\right]$} \\
\hline & 200 & 225 & 250 \\
\hline Mass of Açaí Seeds [g] & 73.50 & 73.50 & 73.50 \\
\hline Moisture Content of Açaí Seeds [wt.\%] & 25.23 & 25.23 & 25.23 \\
\hline Mass of $\mathrm{H}_{2} \mathrm{O}$ in Açaí Seeds [g] & 18.54 & 18.54 & 18.54 \\
\hline Mass of $\mathrm{H}_{2} \mathrm{O}[\mathrm{g}]$ & 531.01 & 531.01 & 531.01 \\
\hline Mechanical Stirrer Speed [rpm] & 90 & 90 & 90 \\
\hline Initial Temperature $\left[{ }^{\circ} \mathrm{C}\right]$ & 30 & 30 & 30 \\
\hline Heating Rate $\left[{ }^{\circ} \mathrm{C} / \mathrm{min}\right]$ & 2 & 2 & 2 \\
\hline Process Time $[\mathrm{min}]$ & 240 & 240 & 240 \\
\hline Volume of Gas [mL], T $=25^{\circ} \mathrm{C}, \mathrm{P}=1 \mathrm{~atm}$ & 1395 & 2475 & 3215 \\
\hline $\mathrm{CO}_{2}[\mathrm{vol} . \%]$ & 48.60 & 44.80 & 35.80 \\
\hline $\mathrm{CH}_{4}[\mathrm{vol} . \%]$ & 1.90 & 1.20 & 0.60 \\
\hline $\mathrm{O}_{2}[\mathrm{vol} . \%]$ & 9.20 & 9.90 & 12.10 \\
\hline $100-\Sigma\left(\mathrm{CO}_{2}+\mathrm{CH}_{4}+\mathrm{O}_{2}\right)[\mathrm{vol} . \%]$ & 40.30 & 44.10 & 51.50 \\
\hline Mass of Gas $[\mathrm{g}]$ & 1.94 & 3.57 & 4.70 \\
\hline Mass of Dry Hydro-char [g] & 30.77 & 29.43 & 28.16 \\
\hline Mass of Liquid Reaction $[\mathrm{g}]$ & 34.72 & 36.01 & 36.59 \\
\hline Yield of Hydro-char [wt.\%] & 41.86 & 40.04 & 38.31 \\
\hline Yield of Liquid Phase [wt.\%] & 47.24 & 48.99 & 49.78 \\
\hline Yield of Gas [wt.\%] & 2.64 & 4.86 & 6.39 \\
\hline
\end{tabular}

Figure 6 compares the yields of solid-phase products as a function of temperature by hydrothermal processing of Açaí seeds from nature with hot compressed $\mathrm{H}_{2} \mathrm{O}$ at 175 , 200,225 , and $250{ }^{\circ} \mathrm{C}$, heated $2{ }^{\circ} \mathrm{C} /$ minovery $240 \mathrm{~min}$, and biomass-to-water ratio of 1:10, in laboratory and pilot scales. One can observe, for the temperature interval $200-250{ }^{\circ} \mathrm{C}$, that the yield of solid-phase products varied between 39.53 and $37.01 \%$ (wt.) in pilot scale, while that in the laboratory varied between 41.86 and $38.31 \%$ (wt.), showing deviations between 5.56 and $3.39 \%$. The yield of solid-phase products at laboratory and pilot scales are very close, showing that production scales had little effect on hydro-char yield. A linear function was applied to regress the yield of hydro-char at a laboratory scale, correlating very well to the experimental data, with an $\mathrm{r}^{2}$ (R-Squared) of 0.999 .

Influence of Biomass-to-Water Ratio on the Yields of Reaction Products

Table 4 describes in detail the material balances, operating conditions, and yields of reaction products by hydrothermal processing of Açaí seeds in nature at $250{ }^{\circ} \mathrm{C}, 2{ }^{\circ} \mathrm{C} / \mathrm{min}$, $240 \mathrm{~min}$, and biomass-to-water ratios of 1:10, 1:15, and 1:20 pilot scale. 


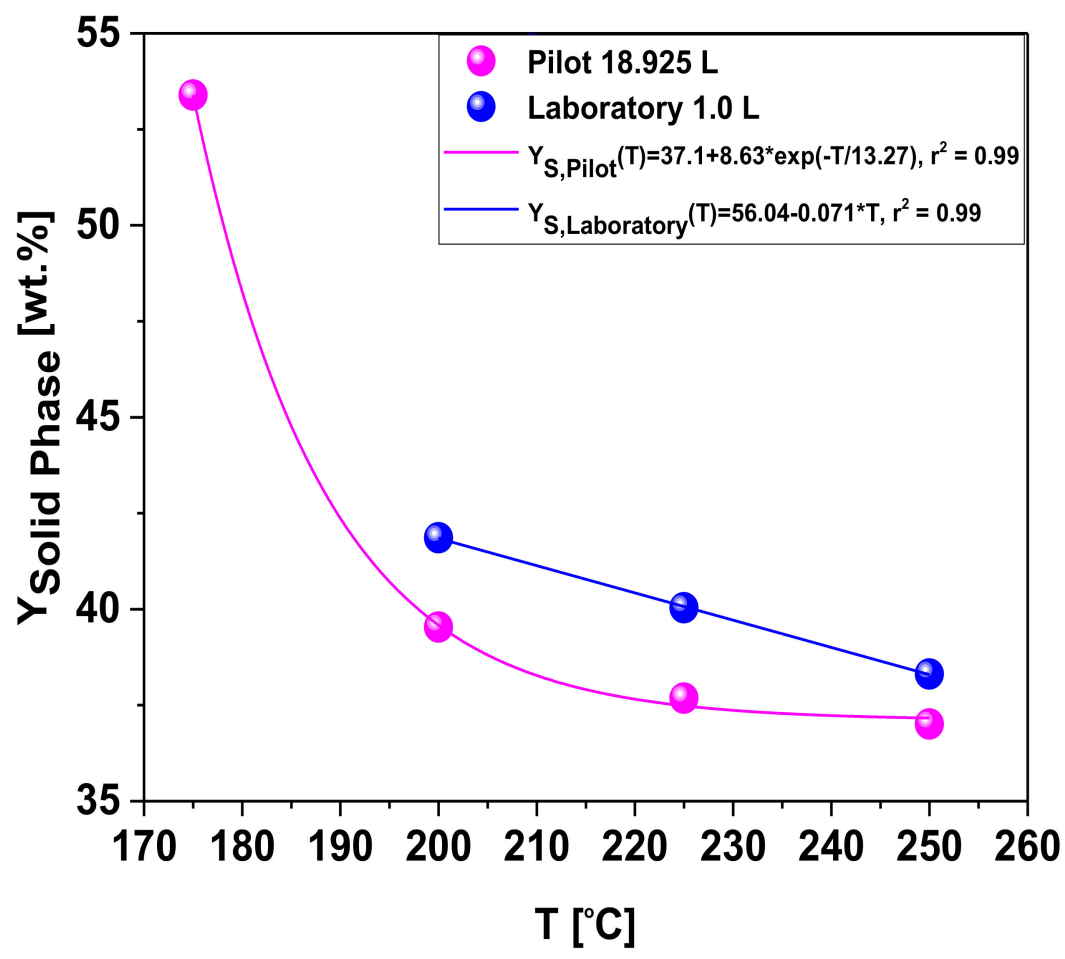

Figure 6. Influence of temperature on the solid phase yield by hydrothermal processing of Açaí seeds in nature at laboratory and pilot scales.

Table 4. Mass balances, processes, operating conditions, and yields of solid, liquid, and gaseous phases by hydrothermal processing of Açaí seeds with hot compressed $\mathrm{H}_{2} \mathrm{O}$ at $250{ }^{\circ} \mathrm{C}, 2{ }^{\circ} \mathrm{C} / \mathrm{min}$, $240 \mathrm{~min}$, and biomass-to-water ratios of 1:10, 1:15, and 1:20, in pilot scale.

\begin{tabular}{|c|c|c|c|}
\hline \multirow[b]{3}{*}{ Process Parameters } & \multicolumn{3}{|c|}{$250{ }^{\circ} \mathrm{C}$} \\
\hline & \multicolumn{3}{|c|}{ Biomass $/ \mathrm{H}_{2} \mathrm{O}[-]$} \\
\hline & 1:10 & 1:15 & $1: 20$ \\
\hline Mass of Açaí Seeds [g] & 300.16 & 300.28 & 300.07 \\
\hline Mass of $\mathrm{H}_{2} \mathrm{O}[\mathrm{g}]$ & 2999.90 & 4502.90 & 6000.80 \\
\hline Mechanical Stirrer Speed [rpm] & 90 & 90 & 90 \\
\hline Initial Temperature $\left[{ }^{\circ} \mathrm{C}\right]$ & 30 & 30 & 30 \\
\hline Heating Rate $\left[{ }^{\circ} \mathrm{C} / \mathrm{min}\right]$ & 2 & 2 & 2 \\
\hline Process Time $[\mathrm{min}]$ & 240 & 240 & 240 \\
\hline Mass of Slurry $[\mathrm{g}]$ & 3167.40 & 4696.50 & 6217.40 \\
\hline Volume of Gas [mL], $\mathrm{T}=25^{\circ} \mathrm{C}, \mathrm{P}=1 \mathrm{~atm}$ & 7470 & 1240 & 1225 \\
\hline Mass of Gas [g] & 11.408 & 1.905 & 1.863 \\
\hline Process Loss (I) $[\mathrm{g}]$ & 132.66 & 106.68 & 83.47 \\
\hline Input Mass of Slurry (Pressing) [g] & 3161.70 & 4696.50 & 6209.30 \\
\hline Process Loss (II) [g] & 5.70 & 0.00 & 8.10 \\
\hline Mass of Liquid Phase [g] & 2556.96 & 4077.05 & 5663.60 \\
\hline Mass of Moist Hydro-char [g] & 591.29 & 585.83 & 518.45 \\
\hline Process Loss (III) [g] & 13.41 & 33.62 & 35.35 \\
\hline Mass of Dry Hydro-char $[\mathrm{g}]$ & 111.092 & 102.25 & 96.302 \\
\hline $\begin{array}{l}\text { (Mass of Liquid Phase }+\sum \text { Process Loss }+ \text { Mass } \\
\text { of Moist Hydro-char }- \text { Mass of Dry Hydro-char } \\
\text { - Mass of Gas) [g] }\end{array}$ & 3177.52 & 5000.795 & 6210.805 \\
\hline Process Loss $(\mathrm{I}+\mathrm{II}+\mathrm{III})[\mathrm{g}]$ & 151.77 & 140.30 & 126.92 \\
\hline Mass of Liquid ${ }_{\text {Reaction }}[\mathrm{g}]$ & 177.62 & 196.125 & 202.535 \\
\hline Yield of Hydro-char [wt.\%] & 37.011 & 34.051 & 32.093 \\
\hline Yield of Liquid Phase [wt.\%] & 59.188 & 65.315 & 67.286 \\
\hline Yield of Gas [wt.\%] & 3.801 & 0.634 & 0.621 \\
\hline
\end{tabular}


The effect of the $\mathrm{H}_{2} \mathrm{O}$-to-biomass ratio on the yields of reaction products (solid, liquid, and gas) by hydrothermal processing of Açaí seeds in nature is illustrated in Figure 7, and comparison of hydro-char yields with similar data reported in the literature is shown in Figure 8 . At $250{ }^{\circ} \mathrm{C}$, hydrothermal liquefaction is dominant, as the main reaction products formed are liquids [15]. The yields of reaction products, illustrated in Figure 7, were regressed using a dose-response function, showing an $\mathrm{r}^{2}$ (R-Squared) between 0.97 and 0.99. The yields of hydro-char and gas decrease with $\mathrm{H}_{2} \mathrm{O}$-to-water ratios, while that of the liquid phase increases. With an increased $\mathrm{H}_{2} \mathrm{O}$-to-biomass ratio, the amount of reaction media (hot compressed $\mathrm{H}_{2} \mathrm{O}$ ) increases, increasing the number of hydroxonium ions $\left(\mathrm{H}_{3} \mathrm{O}^{+}\right)$ and hydroxide ions $\left(\mathrm{OH}^{-}\right)$dissociated within the reaction system, thus improving the catalyses of chemical reactions such as hydrolysis and organic compound degradation (e.g., depolymerization, fragmentation) without the aid of a catalyst [23]. In fact, according to the literature $[24,25]$, increasing the $\mathrm{H}_{2} \mathrm{O}$-to-biomass ratio causes a great impact on hydrolysis reactions by hydrothermal processing of biomass.

A compilation of similar data on the effect of the $\mathrm{H}_{2} \mathrm{O}$-to-biomass ratio over hydro-char yields is illustrated in Figure 8. The behavior of the hydro-char yield is similar, showing a decrease in the hydro-char yield as the $\mathrm{H}_{2} \mathrm{O}$-to-biomass ratio increases. The data for Açaí seeds, tomato-peel-waste [26], olive stone [27], and corn stalk [19] were regressed using a dose-response function, showing an $\mathrm{r}^{2}$ between 0.941 and 0.969 . The experimental data not only resemble similar data reported in the literature for tomato-peel-waste [26], olive stone [27], microalgae [28], sawdust [29], banana peels [30], and wood chips [25] but are close to those of corn stalk [19] carried out at $250{ }^{\circ} \mathrm{C}$ and $4.0 \mathrm{~h}$.

By analyzing Figure 8, one can observe that temperature has a combined effect on the hydro-char yield with varying $\mathrm{H}_{2} \mathrm{O}$-to-biomass ratios. At higher temperatures $\left(250{ }^{\circ} \mathrm{C}\right)$, the effect of $\mathrm{H}_{2} \mathrm{O}$-to-biomass is more intense, playing an important role in hydro-char yield. For low-medium hydrothermal processing temperatures, the effect of $\mathrm{H}_{2} \mathrm{O}$-to-biomass on hydro-char yield is secondary, as reported by [26].

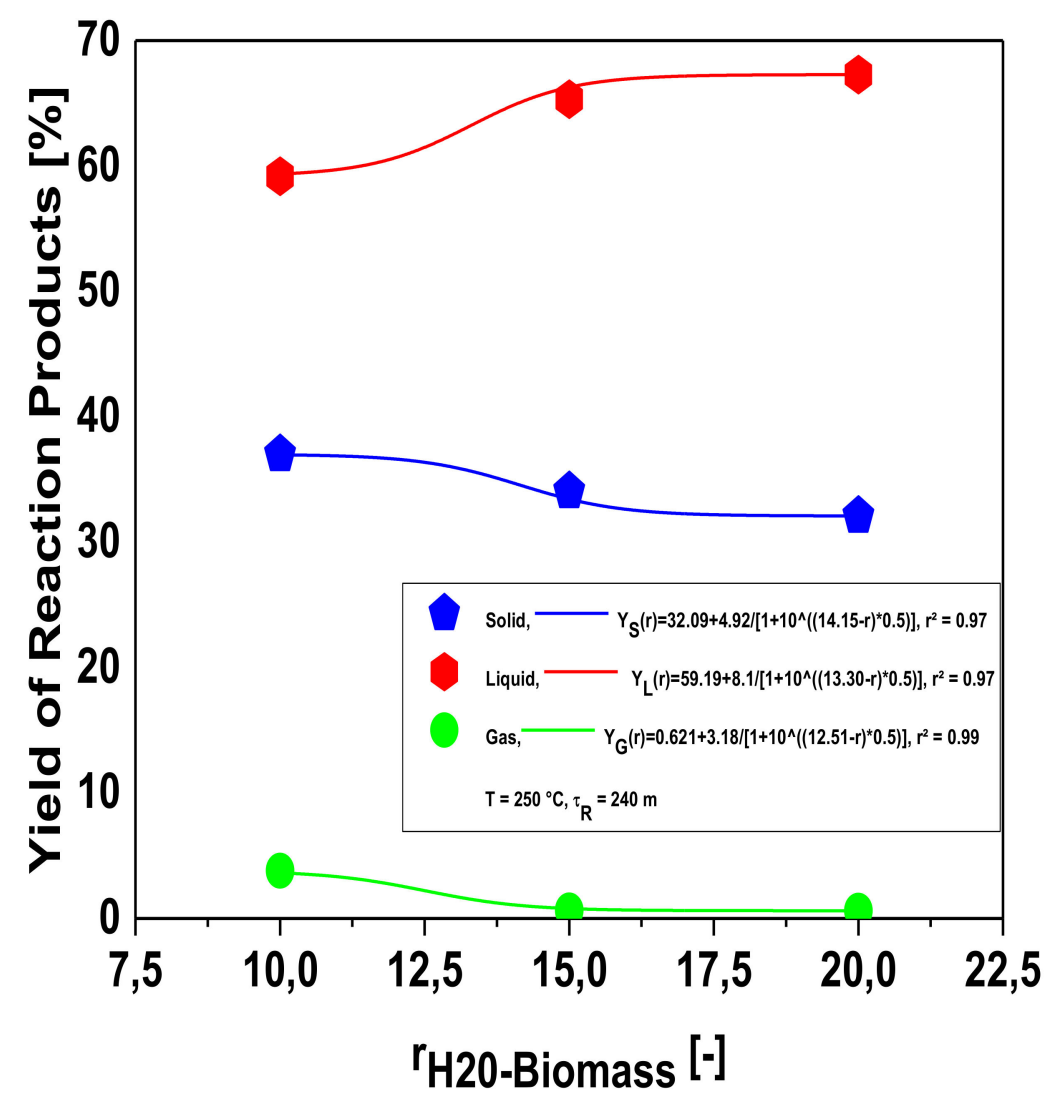

Figure 7. Effect of $\mathrm{H}_{2} \mathrm{O}$-to-biomass ratio on the yields of reaction products. 


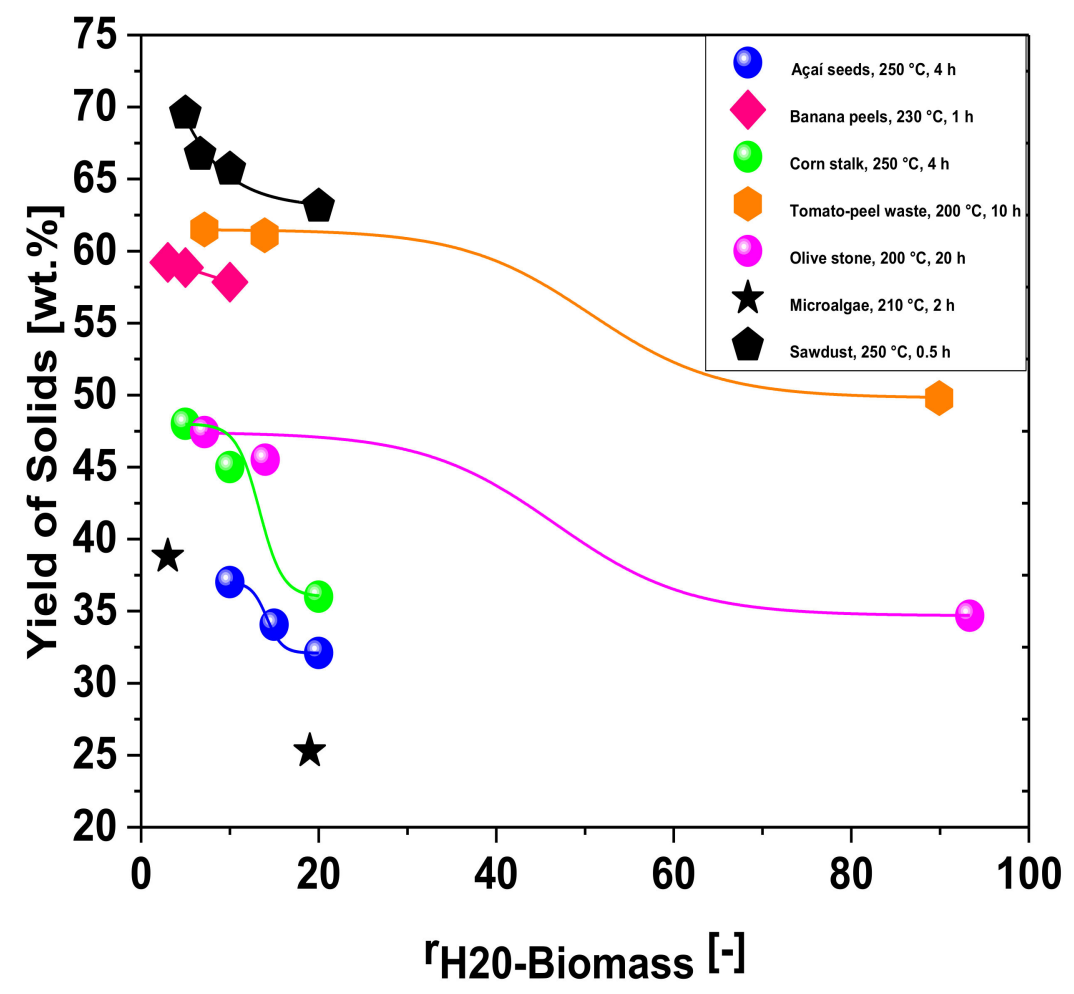

Figure 8. Comparison of hydro-char yield with similar data in the literature [19,26-29].

3.1.2. Chemical Composition of Gas Reaction Products

Influence of Temperature on the Chemical Composition of Gas Reaction Products

The volume of gas degassed at $25^{\circ} \mathrm{C}$ and 1.0 atmosphere by hydrothermal processing of Açaí seeds with hot compressed $\mathrm{H}_{2} \mathrm{O}$ at $175,200,225$, and $250{ }^{\circ} \mathrm{C}$, heated by $2{ }^{\circ} \mathrm{C} / \mathrm{min}$ over $240 \mathrm{~min}$, and biomass-to-water ratio of 1:10, at pilot scale, is shown in Table 5.

Table 5. Volume of gas and composition of gas products at $25^{\circ} \mathrm{C}$ and 1.0 atmosphere by hydrothermal processing of Açaí seeds with hot compressed $\mathrm{H}_{2} \mathrm{O}$ at $175,200,225,250{ }^{\circ} \mathrm{C}, 2^{\circ} \mathrm{C} / \mathrm{min}, 240 \mathrm{~min}$, and biomass-to-water ratio of 1:10, in pilot scale.

\begin{tabular}{|c|c|c|c|c|}
\hline \multirow[b]{2}{*}{ Composition [vol.\%] } & \multicolumn{4}{|c|}{ Temperature $\left[{ }^{\circ} \mathrm{C}\right]$} \\
\hline & 175 & 200 & 200 & 200 \\
\hline $\mathrm{CO}_{2}[\mathrm{vol} . \%]$ & 0.00 & 44.40 & 51.30 & 60.60 \\
\hline $\mathrm{CH}_{4}[\mathrm{vol} . \%]$ & 0.00 & 0.40 & 0.50 & 1.30 \\
\hline $\mathrm{O}_{2}[\mathrm{vol} . \%]$ & 0.00 & 1.0 & 0.30 & 0.00 \\
\hline $100-\Sigma\left(\mathrm{CO}_{2}+\mathrm{CH}_{4}+\mathrm{O}_{2}\right)[$ vol. $\%]$ & 0.00 & 54.20 & 47.90 & 38.10 \\
\hline Volume of Gas [mL] & 0.00 & 5290 & 5590 & 7470 \\
\hline Volume of $\mathrm{CO}_{2}[\mathrm{~mL}]$ & 0.00 & 2348.76 & 2867.67 & 4526.82 \\
\hline Volume of $\mathrm{CH}_{4}[\mathrm{~mL}]$ & 0.00 & 21.16 & 27.95 & 97.11 \\
\hline Volume of $\mathrm{O}_{2}[\mathrm{~mL}]$ & 0.00 & 52.90 & 16.77 & 0.00 \\
\hline $\mathrm{V}_{100-\Sigma(\mathrm{CO} 2+\mathrm{CH} 4+\mathrm{O} 2)} \approx \mathrm{V}_{\mathrm{CO}}[\mathrm{mL}]$ & 0.00 & 2867.18 & 2677.61 & 2846.07 \\
\hline Mass of Gas $[\mathrm{g}]$ & 0.00 & 7.564 & 8.231 & 11.408 \\
\hline Mass of $\mathrm{CO}_{2}[\mathrm{~g}]$ & 0.00 & 4.191 & 5.117 & 8.078 \\
\hline Mass of $\mathrm{CH}_{4}[\mathrm{~g}]$ & 0.00 & 0.014 & 0.018 & 0.063 \\
\hline Mass of $\mathrm{O}_{2}[\mathrm{~g}]$ & 0.00 & 0.068 & 0.022 & 0.000 \\
\hline Mass of CO $[\mathrm{g}]$ & 0.00 & 3.291 & 3.074 & 3.267 \\
\hline \multicolumn{5}{|l|}{ Composition of Gas [mol.\%] } \\
\hline $\mathrm{Y}^{\mathrm{CO} 2}$ & 0.00 & 0.441410 & 0.510306 & 0.603507 \\
\hline $\mathrm{YCH} 4$ & 0.00 & 0.004055 & 0.004936 & 0.012943 \\
\hline $\mathrm{Y}^{\mathrm{O} 2}$ & 0.00 & 0.009848 & 0.003017 & 0.000000 \\
\hline 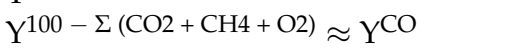 & 0.00 & 0.544687 & 0.481741 & 0.383550 \\
\hline
\end{tabular}


Figure 9 illustrates the effect of process temperature on the volume of gas degassed at $25^{\circ} \mathrm{C}$ and 1.0 atmosphere and the volumetric composition of gaseous products shown in Figure 10. The volume of gas increases exponentially as the process temperature increases, and the same behavior was reported for the hydrothermal carbonization of corn stover by Machado et al. [14]. Similar studies reported that the volume of gaseous products increases with temperature $[18,31,32]$.

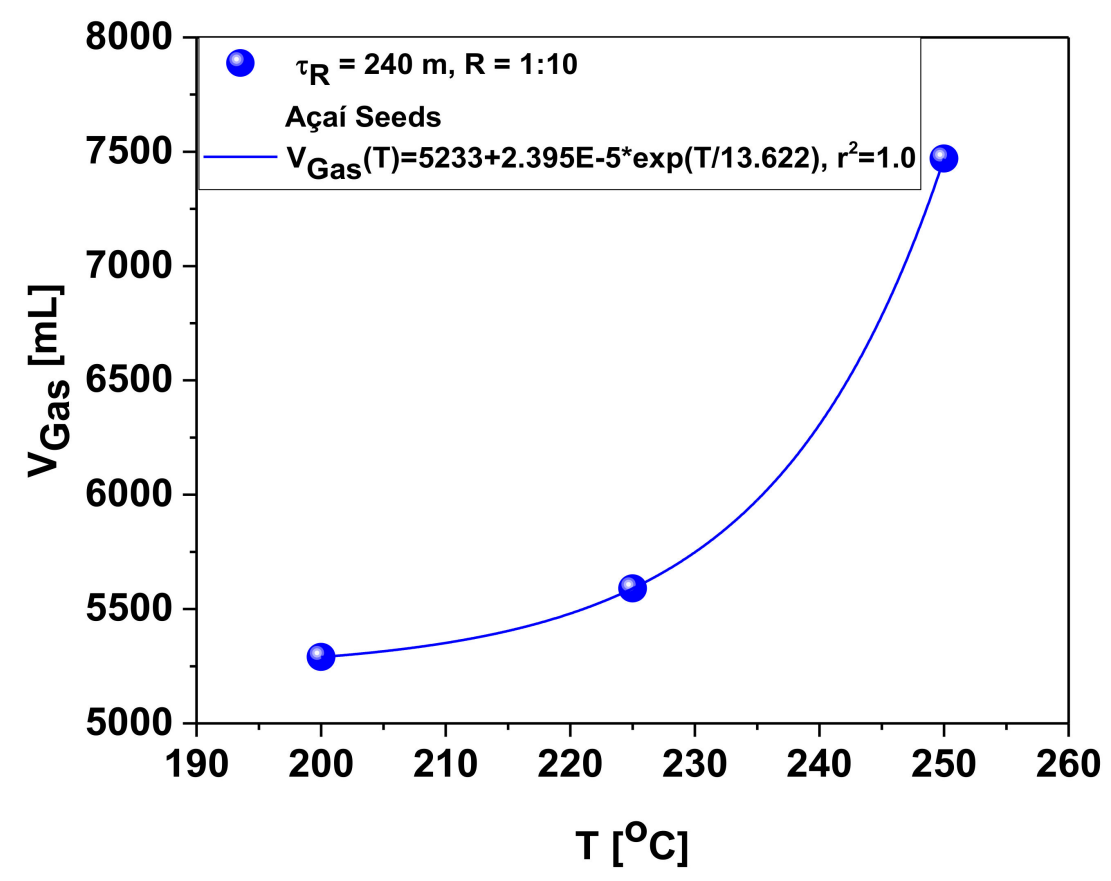

Figure 9. Effect of process temperature on the volume of gas degassed at $25^{\circ} \mathrm{C}$ and 1.0 atmosphere.

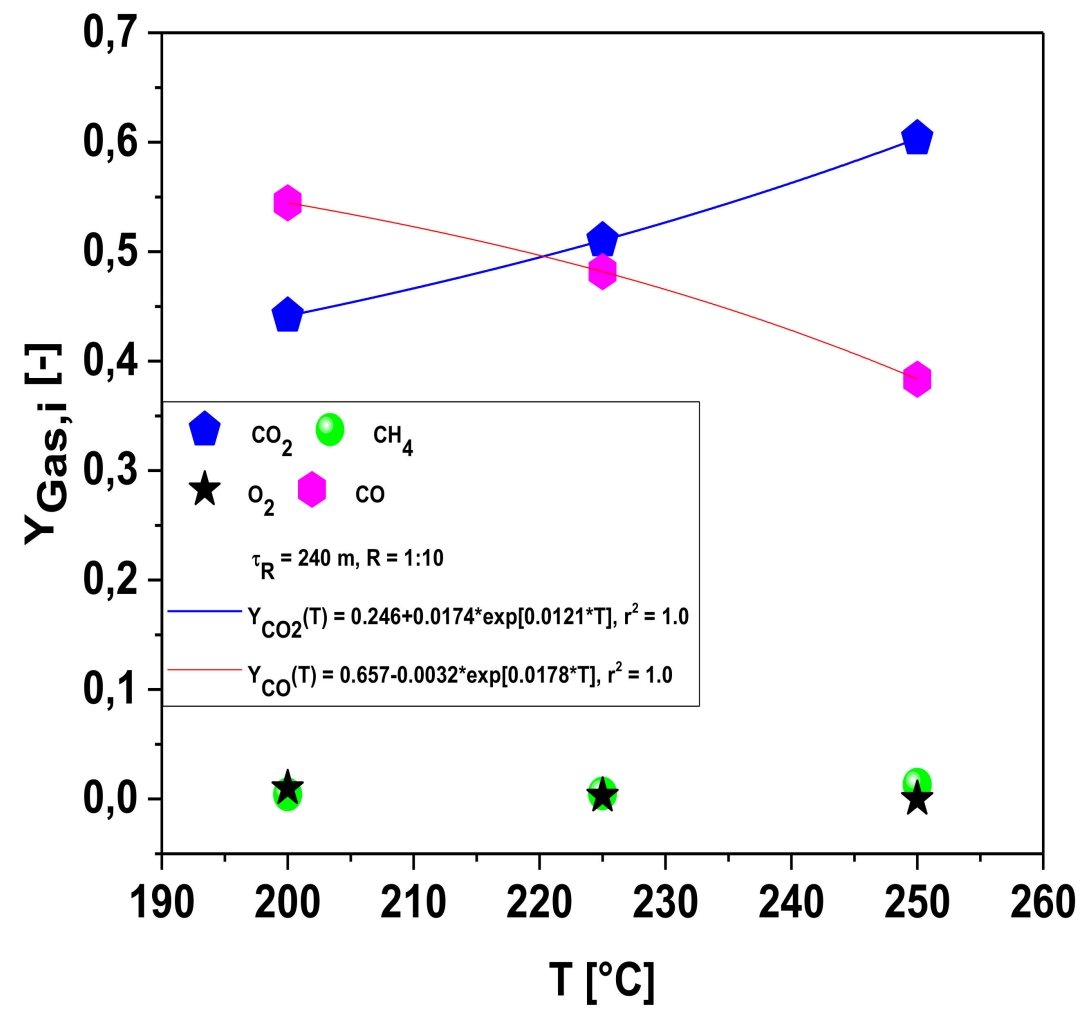

Figure 10. Effect of process temperature on the chemical composition of gas reaction products, expressed in mole fractions. 
The infrared gas analyzer identified the presence of $\mathrm{CO}_{2}, \mathrm{O}_{2}, \mathrm{CH}_{4}$, and $\mathrm{CO}$, which was computed by difference [14], as summarized in Table 5, with $\mathrm{CO}_{2}$ being the most abundant gaseous species produced. This is in accordance with similar studies on the evaluation of gaseous products and compositions by hydrothermal processing of biomass $[14,18,31,33,34]$. The presence of high volumetric concentrations of $\mathrm{CO}_{2}$ in the gaseous phase indicates that decarboxylation is probably one of the dominant reaction mechanisms/pathways by hydrothermal processing of Açaí seeds in nature, according to Li et al. [35]. In fact, according to the literature [36], by hydrothermal processing of biomass, decarboxylation takes place, yielding $\mathrm{CO}_{2}$, but other sources can also produce $\mathrm{CO}_{2}$, including the decomposition of $\mathrm{HCOOH}$, produced during the hydrothermal degradation of cellulose, and until condensation reactions occur.

The effect of temperature on the chemical composition of gas reaction products is shown in Figure 10. The mole fraction of CO shows a smooth exponential decay behavior, and the mole fraction of $\mathrm{CO}_{2}$ shows a smooth exponential growth. An increase in $\mathrm{CO}_{2}$ concentration in the gaseous phase by hydrothermal processing of biomass may be explained by analogy to the mild torrefaction process of biomass, as reported by Wannapeera et al. [37]. By increasing the processing temperature, the oxygen functional groups in the Açaí seeds are decomposed, resulting not only in higher amounts of gas formed but also in higher yields of $\mathrm{CO}_{2}$.

Influence of $\mathrm{H}_{2} \mathrm{O}$-to-Biomass Ratio on the Volume of Gas Reaction Products

The effect of $\mathrm{H}_{2} \mathrm{O}$-to-biomass ratio on the volume of gas degassed at $25{ }^{\circ} \mathrm{C}$ and 1.0 atmosphere by hydrothermal of Açaí seeds from nature with hot compressed $\mathrm{H}_{2} \mathrm{O}$ at $250{ }^{\circ} \mathrm{C}$, heated by $2{ }^{\circ} \mathrm{C} / \mathrm{min}$ over $240 \mathrm{~min}$, and biomass-to-water ratios of $1: 10,1: 15$, and 1:20, at a pilot scale, illustrated in Table 6 and Figure 11. By increasing the $\mathrm{H}_{2} \mathrm{O}$-to-Biomass ratio, the volume of gas depletes, indicating that hydrolysis may be the dominant reaction mechanism $[24,38]$.

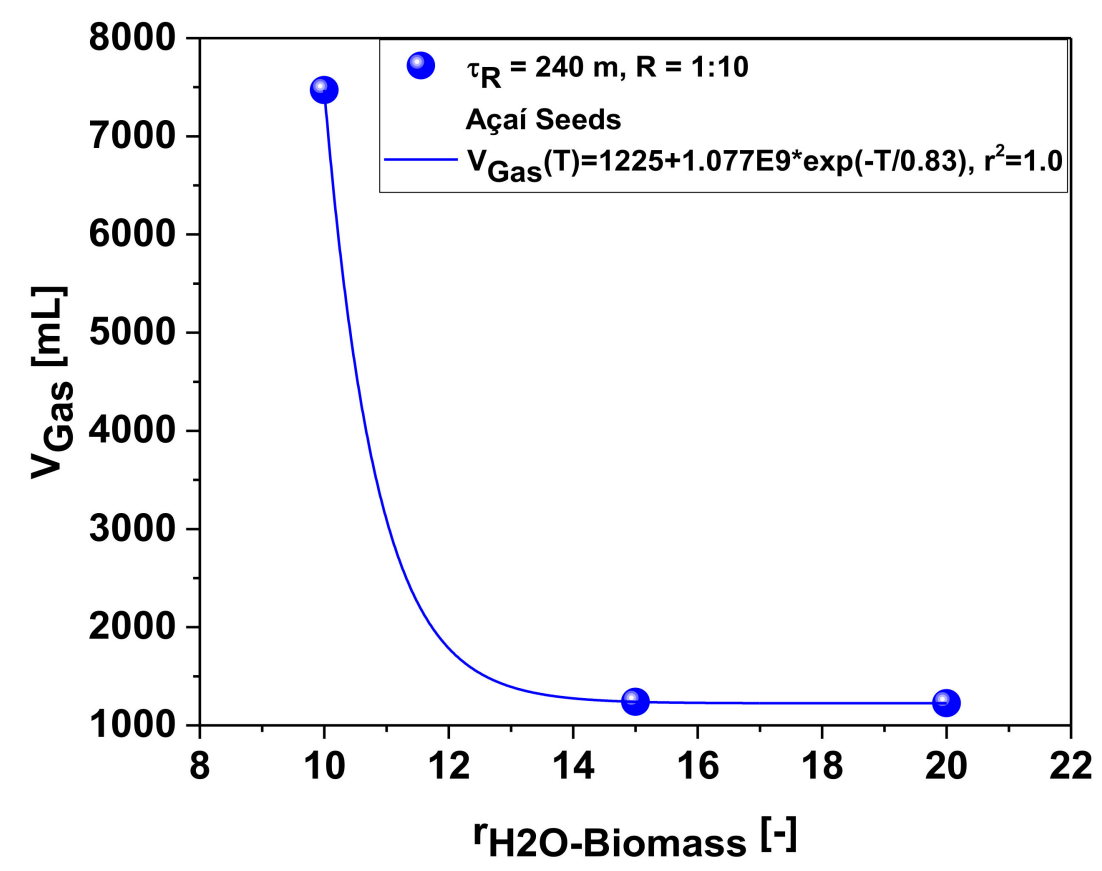

Figure 11. Effect of $\mathrm{H}_{2} \mathrm{O}$-to-biomass on the volume of gas degassed at $25^{\circ} \mathrm{C}$ and 1.0 atmosphere by hydrothermal processing of Açaí seeds with hot compressed $\mathrm{H}_{2} \mathrm{O}$. 
Table 6. Volume of gas and composition of gas products at $25^{\circ} \mathrm{C}$ and 1.0 atmosphere as a function of temperature by hydrothermal processing of Açaí seeds with hot compressed $\mathrm{H}_{2} \mathrm{O}$ at $250{ }^{\circ} \mathrm{C}$, $2{ }^{\circ} \mathrm{C} / \mathrm{min}, 240 \mathrm{~min}$, and biomass-to-water ratios of 1:10, 1:15, and 1:20, in pilot scale.

\begin{tabular}{|c|c|c|c|}
\hline \multirow[b]{3}{*}{ Composition [vol.\%] } & \multicolumn{3}{|c|}{$250^{\circ} \mathrm{C}$} \\
\hline & \multicolumn{3}{|c|}{ Biomass/ $\mathrm{H}_{2} \mathrm{O}[-]$} \\
\hline & 1:10 & 1:15 & 1:20 \\
\hline $\mathrm{CO}_{2}[\mathrm{vol} . \%]$ & 60.60 & 63.40 & 59.90 \\
\hline $\mathrm{CH}_{4}[$ vol. $\%]$ & 1.30 & 3.10 & 1.60 \\
\hline $\mathrm{O}_{2}[\mathrm{vol} . \%]$ & 0.00 & 0.00 & 0.00 \\
\hline$\Sigma\left(\mathrm{CO}_{2}+\mathrm{CH}_{4}+\mathrm{O}_{2}\right)$ & 61.90 & 65.50 & 61.50 \\
\hline $100-\Sigma\left(\mathrm{CO}_{2}+\mathrm{CH}_{4}+\mathrm{O}_{2}\right)[$ vol. $\%]$ & 38.10 & 33.50 & 38.50 \\
\hline Volume of Gas $[\mathrm{mL}]$ & - & - & - \\
\hline Volume of $\mathrm{CO}_{2}[\mathrm{~mL}]$ & 4526.82 & 786.16 & 733.775 \\
\hline Volume of $\mathrm{CH}_{4}[\mathrm{~mL}]$ & 97.11 & 38.44 & 19.60 \\
\hline Volume of $\mathrm{O}_{2}[\mathrm{~mL}]$ & 0.00 & 00.00 & 00.00 \\
\hline $\mathrm{V}_{100-\Sigma(\mathrm{CO} 2+\mathrm{CH} 4+\mathrm{O} 2)} \approx \mathrm{V}_{\mathrm{CO}}[\mathrm{mL}]$ & 2846.07 & 415.40 & 471.625 \\
\hline
\end{tabular}

3.1.3. Chemical Composition of Organic Compounds in the Aqueous Phase Effect of Temperature on the Chemical Composition of Organic Compounds in the Aqueous Phase

The effect of temperature on the concentration profile of aromatic-ring compounds (furfural, $\mathrm{HMF}$, phenols, and catechol) and carboxylic acids $\left(\mathrm{CH}_{3} \mathrm{COOH}, \mathrm{CH}_{3} \mathrm{CH}_{2} \mathrm{COOH}\right.$ ) by hydrothermal processing of Açaí seeds is illustrated in Figures 12-14, and the data are summarized in Table 7.

Figure 12 compares the concentration of HMF in the aqueous phase as a function of temperature by hydrothermal processing of Açaí seeds in nature with hot compressed $\mathrm{H}_{2} \mathrm{O}$ at $175,200,225,250{ }^{\circ} \mathrm{C}$, heated by $2{ }^{\circ} \mathrm{C} / \mathrm{min}$ over $240 \mathrm{~min}$, and biomass-to-water ratio of 1:10, at laboratory and pilot scales. We observed, for the temperature interval $175-250{ }^{\circ} \mathrm{C}$, at pilot scale, that the concentration of HMF showed a Gaussian distribution. In the temperature interval $200-250^{\circ} \mathrm{C}$, the concentration of $\mathrm{HMF}$ decreased drastically, showing an exponential decay behavior at both pilot and laboratory scales, and was not detectable at $250{ }^{\circ} \mathrm{C}$.

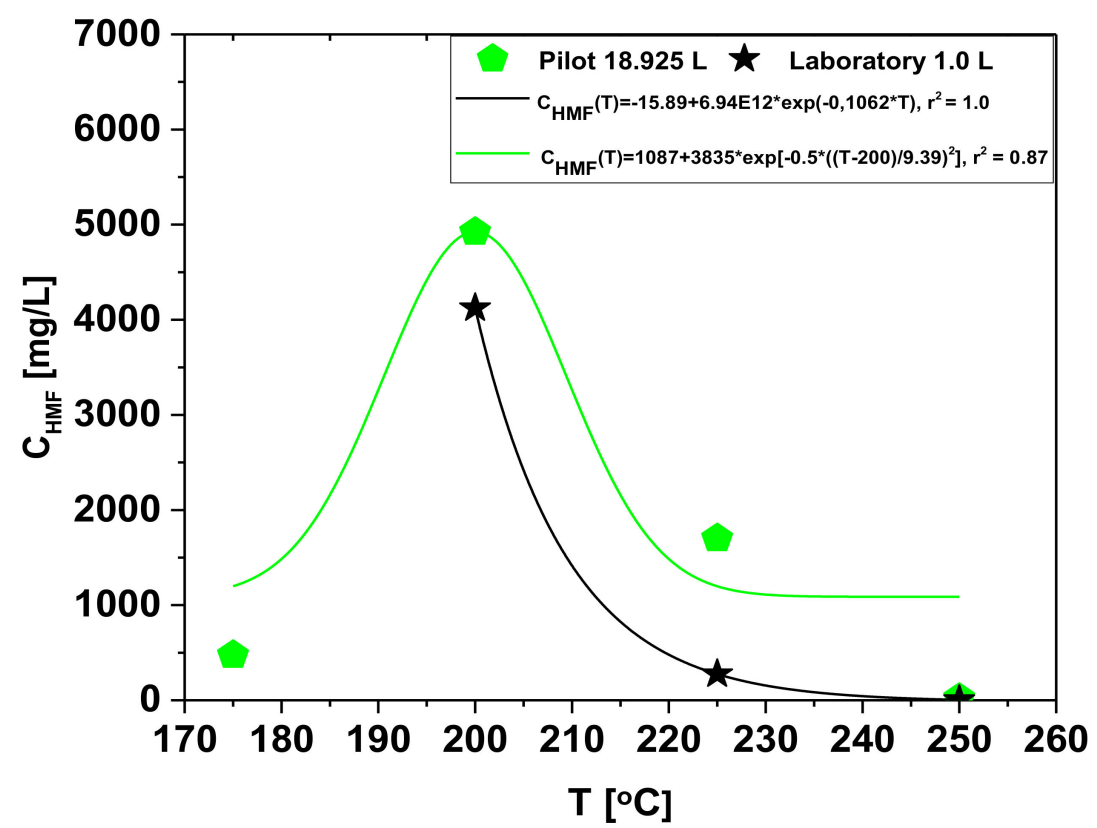

Figure 12. Effect of temperature on the concentration of HMF in the aqueous phase by hydrothermal processing of Açaí seeds from nature at laboratory and pilot scales. 


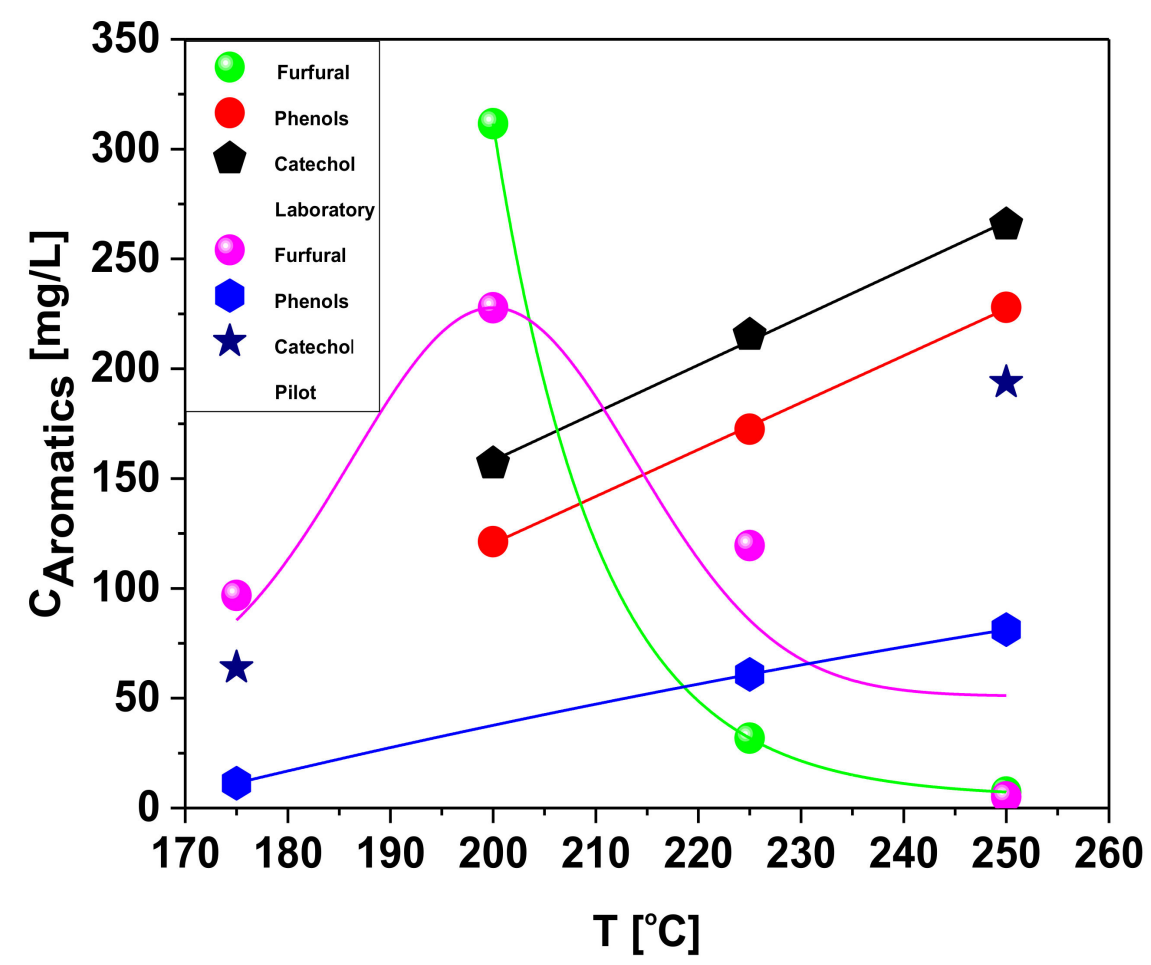

Figure 13. Effect of temperature on the concentration of aromatic compounds (phenols, furfural, and cathecol).

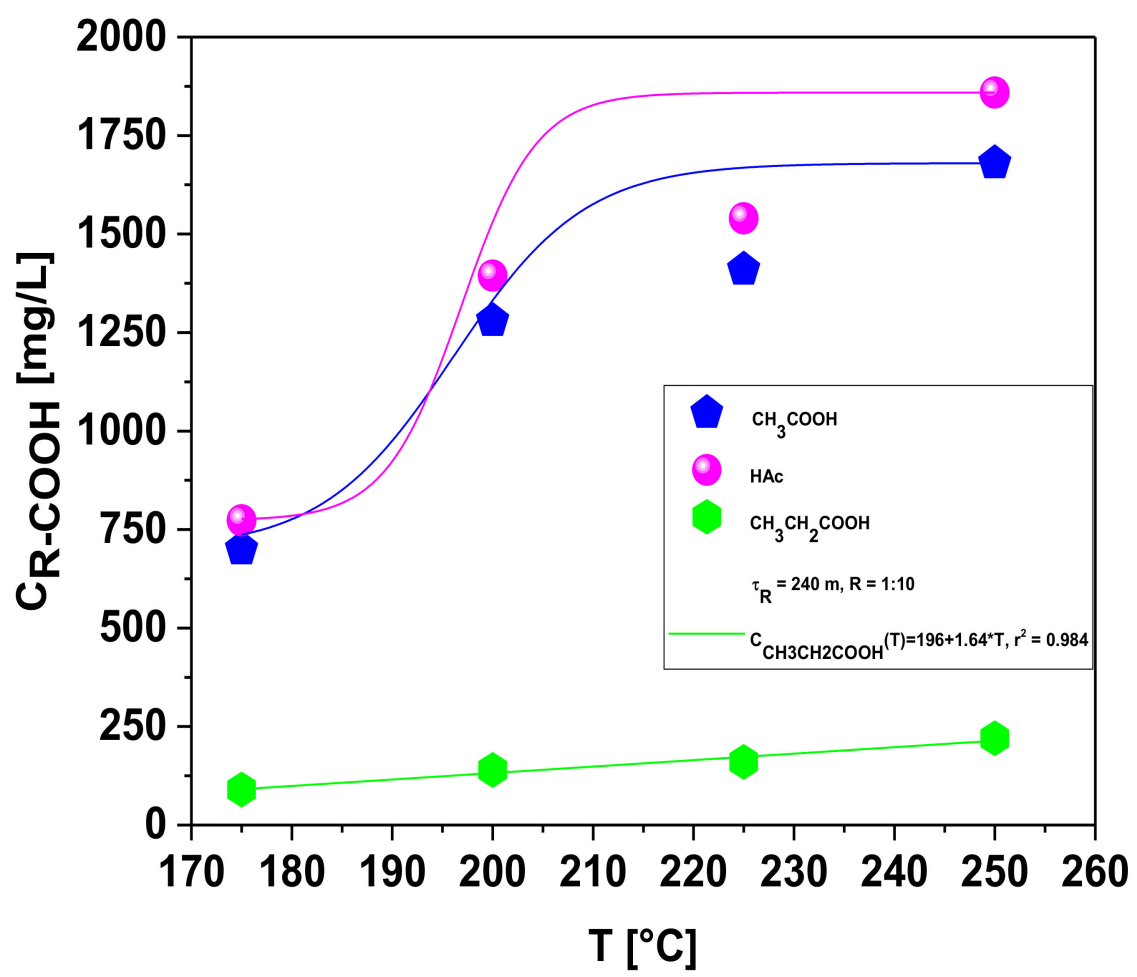

Figure 14. Effect of temperature on the concentration of carboxylic acids $\left(\mathrm{CH}_{3} \mathrm{COOH}\right.$, $\mathrm{CH}_{3} \mathrm{CH}_{2} \mathrm{COOH}$ ) and total carboxylic acids (HAc). 
Table 7. Concentration of aromatics compounds (HMF, furfural, phenol, catechol), carboxylic acids $\left(\mathrm{CH}_{3} \mathrm{COOH}, \mathrm{CH}_{3} \mathrm{CH}_{2} \mathrm{COOH}\right)$, and total carboxylic acids (HAc) in the aqueous phase at $25^{\circ} \mathrm{C}$ and 1.0 atmosphere by hydrothermal processing of Açaí seeds with hot compressed $\mathrm{H}_{2} \mathrm{O}$ at 175, 200, 225, $250{ }^{\circ} \mathrm{C}, 2{ }^{\circ} \mathrm{C} / \mathrm{min}, 240 \mathrm{~min}$, and biomass-to-water ratio of 1:10, at pilot and laboratory scales.

\begin{tabular}{|c|c|c|c|c|}
\hline & \multicolumn{4}{|c|}{ Temperature $\left[{ }^{\circ} \mathrm{C}\right]$} \\
\hline & \multicolumn{4}{|c|}{ Pilot } \\
\hline Concentration of aromatics [mg/L] & 175 & 200 & 225 & 250 \\
\hline HMF: CAS: $67-47-0$ & 474.8 & 4923 & 1701 & 24.45 \\
\hline Furfural: CAS:98-01-1 & 96.83 & 227.8 & 119.5 & 5.05 \\
\hline Phenol: CAS: 108-95-2 & 11.34 & - & 60.81 & 81.24 \\
\hline Catechol: CAS: $120-80-9$ & 63.86 & - & - & 193.8 \\
\hline Concentration of carboxylic acids $[\mathrm{mg} / \mathrm{L}]$ & - & - & - & - \\
\hline Acetic acid: CAS: $64-19-7$ & 700 & 1280 & 1410 & 1680 \\
\hline Total acetic acid (HAc) & 773.2 & 1394 & 1540 & 1859 \\
\hline \multirow[t]{2}{*}{ Propionic Acid: CAS: 79-09-4 } & 90 & 140 & 160 & 220 \\
\hline & \multicolumn{4}{|c|}{ Laboratory } \\
\hline Concentration of aromatics $[\mathrm{mg} / \mathrm{L}]$ & - & 200 & 225 & 250 \\
\hline HMF: CAS: $67-47-0$ & - & 4123 & 275 & 4.56 \\
\hline Furfural: CAS:98-01-1 & - & 311.5 & 31.82 & 7.28 \\
\hline Phenol: CAS: 108-95-2 & - & 121.2 & 172.5 & 227.99 \\
\hline Catechol: CAS: $120-80-9$ & - & 156.84 & 215.4 & 365.61 \\
\hline Concentration of carboxylic acids $[\mathrm{mg} / \mathrm{L}]$ & - & - & - & - \\
\hline Acetic acid: CAS: $64-19-7$ & - & 3420 & 3690 & 3810 \\
\hline Total acetic acid (HAc) & - & 3797 & 3996 & 4286 \\
\hline Propionic Acid: CAS: 79-09-4 & - & 240 & 310 & 410 \\
\hline
\end{tabular}

The concentration of HMF showed the same behavior in the temperature interval $200-250{ }^{\circ} \mathrm{C}$ at laboratory and pilot scales. However, there is a significant difference between concentration values, showing that production scales had a great effect on HMF concentration.

When the process temperature was increased, the concentrations of furfural, a byproduct of cellulose degradation, decreased exponentially in the temperature interval $200-250{ }^{\circ} \mathrm{C}$ and were present at very low concentrations at $250{ }^{\circ} \mathrm{C}$, while the concentrations of phenols and catechol, products of furfural and HMF degradation, increased, as shown in Figure 13.

During hydrothermal processing of biomass, as cellulose hydrolyzes, it forms glucose, being transformed by isomerization reactions into fructose [38]. The decomposition of monosaccharides (glucose, fructose) produces volatile carboxylic acids, dissociating within the reaction media, thus producing hydroxonium ions $\left(\mathrm{H}_{3} \mathrm{O}^{+}\right)$and increasing the ionic product of reacting media, improving the degradation of biomass [38]. The monosaccharides (glucose, fructose) also undergo dehydration and fragmentation reactions, producing furfural-derived compounds (furfural, HMF), as well as acids and aldehydes [38]. Finally, as temperature increases, furfural-derived compounds (furfural, HMF) suffer degradation, producing acids, aldehydes, and phenols [38]. In this context, based on the reaction mechanism described by Sevilla and Fuertes [38], it is expected that, due to increasing process temperature, the concentrations of furfural and HMF will decrease, while those of catechol and phenols will increase. The results align with similar studies reported in the literature [14,18,39-41]. Jung et al. [42] studied the growth mechanism of hydro-char and the kinetic model of fructose degradation by hydrothermal carbonization, concluding that $\mathrm{HMF}$ degrades, forming hydro-char and $\mathrm{H}_{2} \mathrm{O}\left(\mathrm{HMF} \rightarrow\right.$ Hydro-char $\left.+\mathrm{H}_{2} \mathrm{O}\right)$, following first-order kinetics $\frac{\mathrm{d}[\mathrm{Hydro}-\mathrm{char}]}{\mathrm{dt}}=\mathrm{K} \times[\mathrm{HMF}]$. This is according to the results for hydrochar yields in Table 1; that is, the higher the concentration of HMF, the higher the yield of hydro-char.

Figure 14 shows that temperature has a great effect on concentrations of carboxylic acids $\left(\mathrm{CH}_{3} \mathrm{COOH}, \mathrm{CH}_{3} \mathrm{CH}_{2} \mathrm{COOH}\right)$ and total carboxylic acids (HAc) by hydrothermal processing of Açaí seeds with hot compressed $\mathrm{H}_{2} \mathrm{O}$ at $175,200,225,250{ }^{\circ} \mathrm{C}$, heated by 
$2{ }^{\circ} \mathrm{C} / \mathrm{min}$ over $240 \mathrm{~min}$, and biomass-to-water ratio of $1: 10$, at pilot scale. The concentrations of carboxylic acids, particularly $\mathrm{CH}_{3} \mathrm{COOH}$, the most predominant one, and total carboxylic acids (HAc) increase strongly with temperature. With the hydrothermal processing of biomass, the monosaccharides (glucose, fructose) produced by hydrolysis are decomposed, forming volatile carboxylic acids, including acetic and propionic acids [38]. As reported by Hoekman et al. [18,43] and Machado et al. [14], the concentrations of acetic acid and total organic acids produced by hydrothermal processing of different biomass feedstocks increase with temperature. Poerschmann et al. [44] investigated the distribution of main medium molar mass compounds dissolved in process water by hydrothermal carbonization of glucose, fructose, and xylose at 180,220 , and $250{ }^{\circ} \mathrm{C}$ by GC-MS and IC, reporting acetic acid concentrations of 4560 and 3920 for the degradation of glucose and fructose, respectively, at $220^{\circ} \mathrm{C}$ and $2.0 \mathrm{~h}$.

It is known that monosaccharides (glucose, fructose) not only decompose, producing volatile carboxylic acids, but also undergo dehydration and fragmentation reactions, producing furfural-derived compounds (furfural, HMF). According to Kabyemela et al. [45], the reaction mechanism/pathway of cellobiose decomposition in sub- and supercritical $\mathrm{H}_{2} \mathrm{O}\left(300{ }^{\circ} \mathrm{C} / 25 \mathrm{MPa}, 350{ }^{\circ} \mathrm{C} / 25 \mathrm{MPa}, 350{ }^{\circ} \mathrm{C} / 40 \mathrm{MPa}\right.$, and $\left.400{ }^{\circ} \mathrm{C} / 40 \mathrm{MPa}\right)$, follows the sequence: hydrolysis of cellobiose to form glucose, followed by pyrolysis to form glycosyl-erythrose and glycosyl-glycol-aldehyde, which undergo hydrolysis to produce erythrose + glucose/fructose and glycol-aldehyde + glucose/fructose. tTat is, glucoseand fructose are intermediate-reaction products, being produced continuously along the hydrothermal process. However, Hoekman et al. [43] reported that concentrations of glucose/xylose and total sugars decrease with increasing process temperature $(215,235,255$, $275,295{ }^{\circ} \mathrm{C}$ ) from $1.02 \%$ (wt.) to $0.08 \%$ (wt.) and $1.41 \%$ (wt.) to $0.22 \%$ (wt.), respectively, and are not detected at 275 and $295^{\circ} \mathrm{C}$. Therefore, one may suppose that the degradation of monosaccharides (glucose, fructose) is not the only reaction mechanism to produce volatile carboxylic acids by hydrothermal processing of biomass as glucose, which according to Falco et al. [16], starts to be produced at $140^{\circ} \mathrm{C}$, reaches a maximum at $200^{\circ} \mathrm{C}$, and then begins to decompose.

Effect of Biomass-to-Water Ratio on the Chemical Composition of Organic Compounds in the Aqueous Phase

The effect of biomass-to-water ratio on the concentration profile of aromatic-ring compounds (furfural, HMF, phenols, and catechol) and carboxylic acids $\left(\mathrm{CH}_{3} \mathrm{COOH}\right.$, $\mathrm{CH}_{3} \mathrm{CH}_{2} \mathrm{COOH}$ ) by hydrothermal processing of Açaí seeds, illustrated in Figures 15 and 16, and the data are summarized in Table 8.

Table 8. Concentration of aromatics compounds (HMF, furfural, phenol, catechol), carboxylic acids $\left(\mathrm{CH}_{3} \mathrm{COOH}, \mathrm{CH}_{3} \mathrm{CH}_{2} \mathrm{COOH}\right)$, and total carboxylic acids (HAc) in the aqueous phase at $25^{\circ} \mathrm{C}$ and 1.0 atmosphere by hydrothermal processing of Açaí seeds with hot compressed $\mathrm{H}_{2} \mathrm{O}$ at $250{ }^{\circ} \mathrm{C}, 2^{\circ} \mathrm{C} / \mathrm{min}$, $240 \mathrm{~min}$, and biomass-to-water ratio of 1:10, in pilot scale.

\begin{tabular}{lccc}
\hline & & $\mathbf{2 5 0}{ }^{\circ} \mathbf{C}$ \\
\cline { 2 - 4 } & & Biomass/H $\mathbf{H}_{\mathbf{2}}$ [-] \\
\hline Concentration of aromatics [mg/L] & $\mathbf{1 : 1 0}$ & $\mathbf{1 : 2 0}$ \\
HMF: CAS: $67-47-0$ & 24.450 & 5.188 & 3.002 \\
Furfural: CAS:98-01-1 & 5.054 & 2.972 & 2.194 \\
Phenol: CAS: $108-95-2$ & 81.24 & 81.78 & 89.33 \\
Catechol: CAS: $120-80-9$ & 195.6 & 193.8 & 185.9 \\
Concentration of carboxylic acids [mg/L] & - & - & - \\
Acetic acid: CAS: $64-19-7$ & 1680 & 1270 & 1070 \\
Total acetic acid (HAc) & 1859 & 1424 & 1070 \\
Propionic Acid: CAS: $79-09-4$ & 220 & 190 & 20 \\
\hline
\end{tabular}




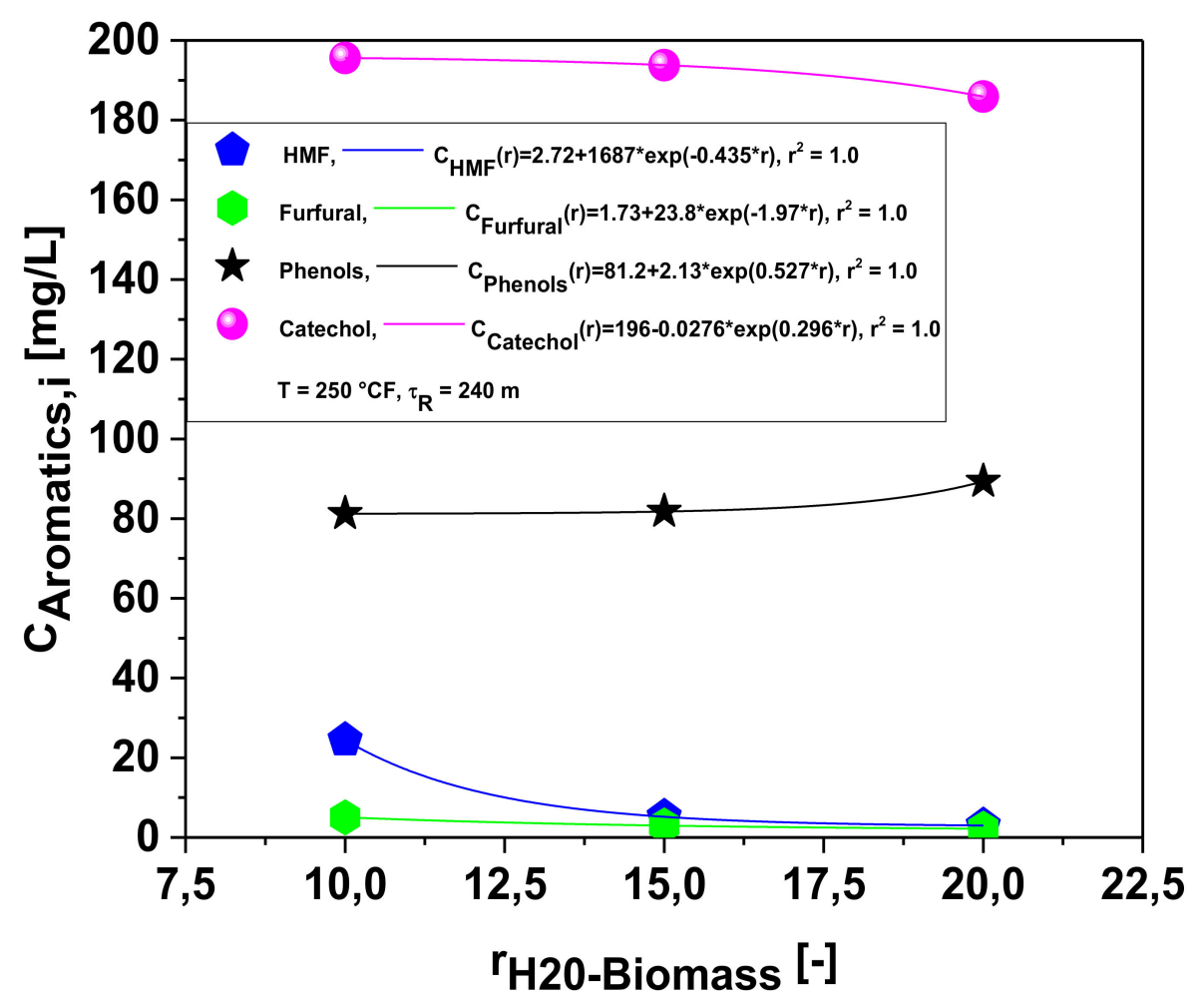

Figure 15. Effect of $\mathrm{H}_{2} \mathrm{O}$-to-biomass ratio on the concentration of aromatic (phenols, furfural, $\mathrm{HMF}$, and catechol).

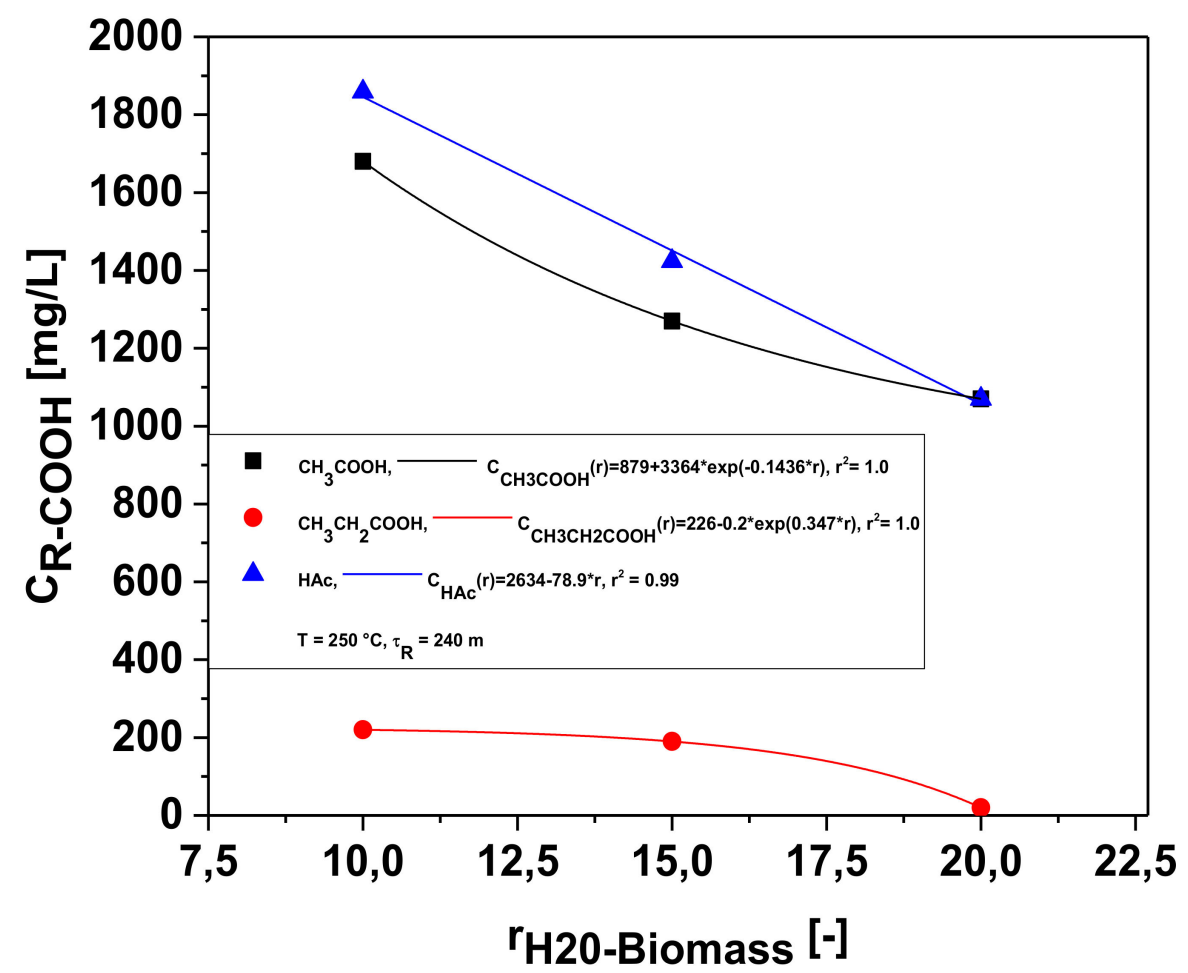

Figure 16. Effect of $\mathrm{H}_{2} \mathrm{O}$-to-biomass ratio on the concentration of carboxylic acids $\left(\mathrm{CH}_{3} \mathrm{COOH}\right.$, $\mathrm{CH}_{3} \mathrm{CH}_{2} \mathrm{COOH}$ ) and total carboxylic acids (HAc).

When the $\mathrm{H}_{2} \mathrm{O}$-to-biomass ratio was increased, the concentrations of furfural and HMF become very low and decrease smoothly, while that of phenols shows a smooth first-order exponential growth behavior, as shown in Figure 15. In addition, the carboxylic 
acids $\left(\mathrm{CH}_{3} \mathrm{COOH}, \mathrm{CH}_{3} \mathrm{CH}_{2} \mathrm{COOH}\right)$ and total carboxylic acids (HAc) also decrease as the $\mathrm{H}_{2} \mathrm{O}$-to-biomass ratio increases, as illustrated in Figure 16. The concentration is measured in $\mathrm{mg} / \mathrm{L}$, so increasing the $\mathrm{H}_{2} \mathrm{O}$-to-biomass ratio increases the volume of reaction, and it is hence expected to decrease the concentration of organic compounds dissolved in processed $\mathrm{H}_{2} \mathrm{O}$.

Effect of Biomass-to-Water Ratio on the Mass Production of Chemicals in the Aqueous Phase

By performing a mass balance by multiplying the concentration of main organic compounds dissolved in process water, described in Table 8 , and the volume of process water (Mass of Liquid Phase $+\sum$ Process Loss + Mass of Moist Hydro-char - Mass of Dry Hydro-char - Mass of Gas), described in Table 4, it can be shown that increasing the $\mathrm{H}_{2} \mathrm{O}$-to-biomass ratio has caused an increase in the mass production of chemicals, including phenols and catechol, products of furfural and HMF degradation, as well as acetic acid as shown in Figures 17 and 18.

According to the literature $[24,25]$, increasing the $\mathrm{H}_{2} \mathrm{O}$-to-biomass ratio causes a great impact on the hydrolysis reactions by hydrothermal processing of the biomass so that the remaining cellulose in biomass is hydrolyzed, producing monosaccharides (glucose, fructose), and the decomposition of monosaccharides (glucose, fructose) produces volatile carboxylic acids, particularly acetic acid (Figure 17). As observed in Figure 17, the mass of furfural and HMF decreases while those of phenols and catechol increase, confirming that furfural and HMF were transformed into phenols and catechol.

It may be concluded that hydrolysis is probably the dominant reaction mechanism, but not the only one, by hydrothermal processing of Açaí seeds with hot compressed $\mathrm{H}_{2} \mathrm{O}$ at $250{ }^{\circ} \mathrm{C}$, heated by $2{ }^{\circ} \mathrm{C} / \mathrm{min}$ over $240 \mathrm{~min}$, as the biomass-to-water ratio increases from $1: 10$ to $1: 20$.

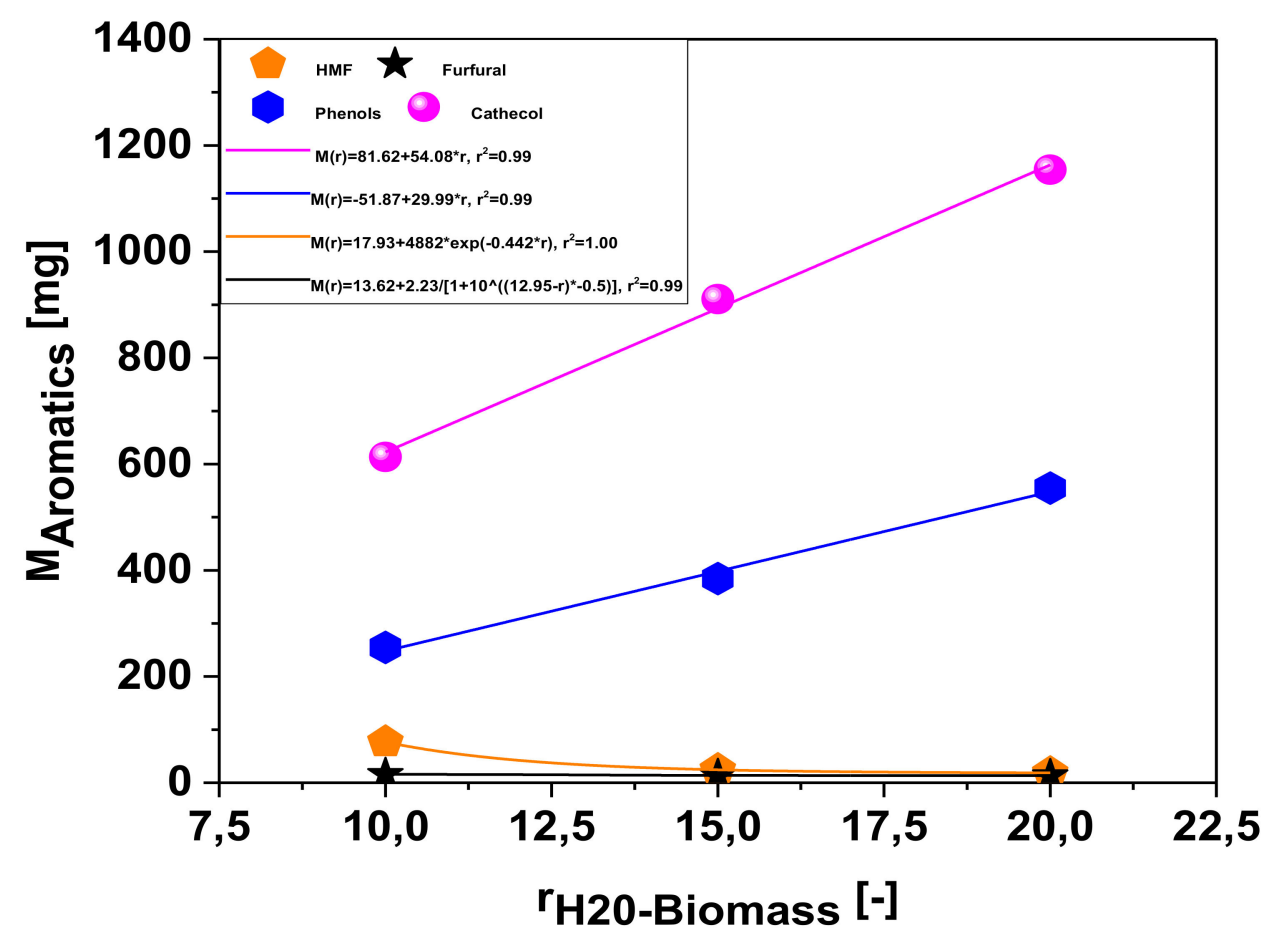

Figure 17. Effect of $\mathrm{H}_{2} \mathrm{O}$-to-biomass ratio on the mass production of acetic acid $\left(\mathrm{CH}_{3} \mathrm{COOH}\right)$. 


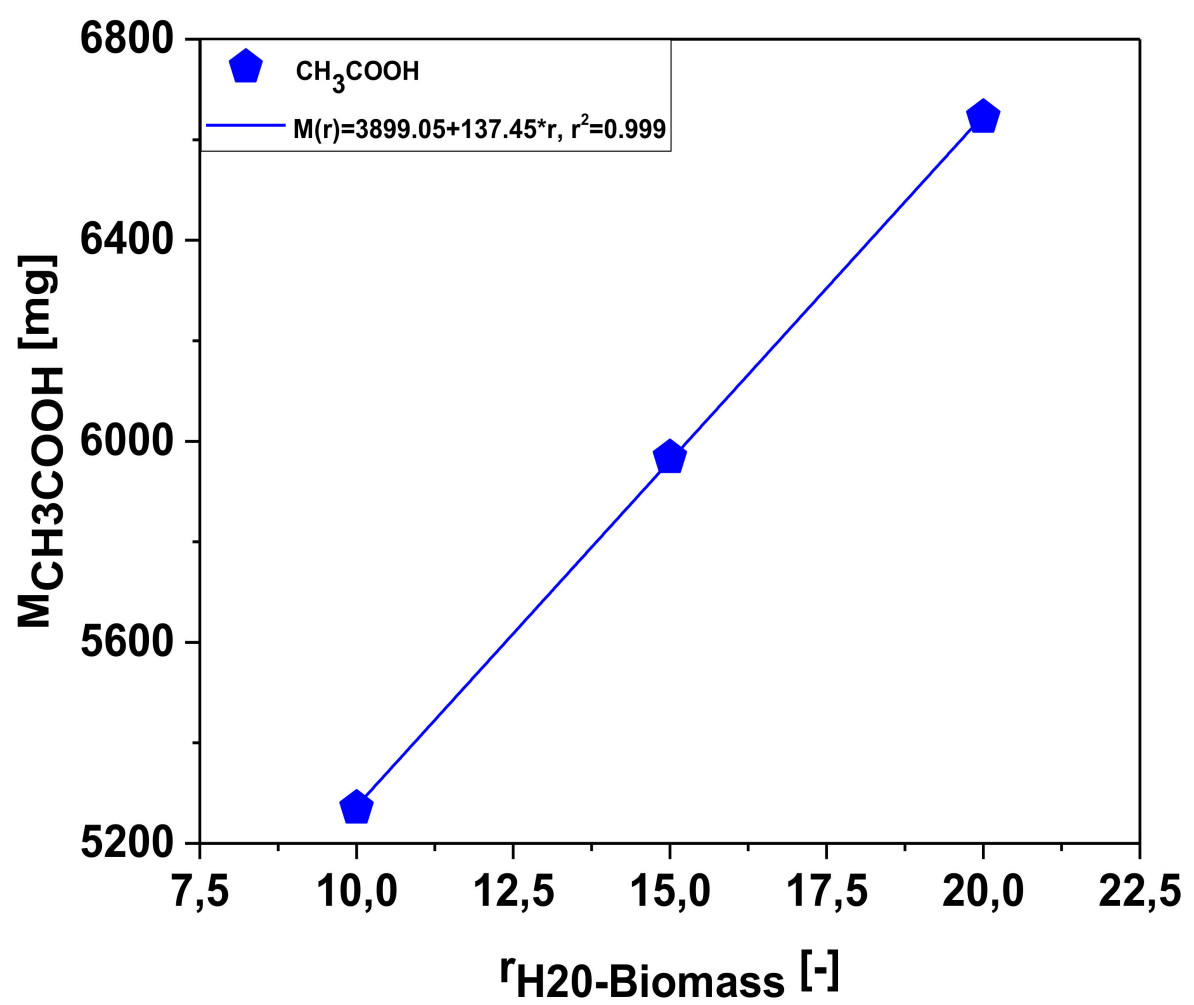

Figure 18. Effect of $\mathrm{H}_{2} \mathrm{O}$-to-biomass ratio on the mass production of aromatic compounds (phenols, catechol).

\section{Conclusions}

Based on the centesimal composition of Açaí (Euterpe oleracea Mart.) seeds, one may perform a centesimal mass balance to compute the approximate theoretical mass degradation of Açaí seeds at $200{ }^{\circ} \mathrm{C}, 2{ }^{\circ} \mathrm{C} / \mathrm{min}, 240 \mathrm{~min}$, and the biomass-to-water ratio of 1:10. The computed solid-phase yield was $38.562 \%$ (wt.), very close to the experimental value of $39.534 \%$ (wt.), showing a deviation of $2.51 \%$.

The yields of hydro-char and gas decrease with $\mathrm{H}_{2} \mathrm{O}$-to-biomass ratios, while that of the liquid phase increases, showing that the $\mathrm{H}_{2} \mathrm{O}$-to-biomass ratio causes a great impact on hydrolysis reactions by hydrothermal processing of the biomass.

The presence of high volumetric concentrations of $\mathrm{CO}_{2}$ in the gaseous phase indicates that decarboxylation is probably one of the dominant reaction mechanisms/pathways by hydrothermal processing of Açaí seeds from nature.

When the $\mathrm{H}_{2} \mathrm{O}$-to-biomass ratio is increased, the concentrations of furfural and HMF are very low and decrease smoothly, while that of phenols shows a smooth first-order exponential growth behavior. In addition, the carboxylic acids $\left(\mathrm{CH}_{3} \mathrm{COOH}, \mathrm{CH}_{3} \mathrm{CH}_{2} \mathrm{COOH}\right)$ and total carboxylic acids (HAc) also decrease as the $\mathrm{H}_{2} \mathrm{O}$-to-biomass ratio increases. By performing a mass balance, it can be shown that increasing the $\mathrm{H}_{2} \mathrm{O}$-to-biomass ratio caused an increase in the mass production of chemicals, including acetic acid, phenols, and catechol.

It may be concluded that hydrolysis is probably the dominant reaction mechanism, but not the only one, by hydrothermal processing of Açaí seeds with hot compressed $\mathrm{H}_{2} \mathrm{O}$ at $250{ }^{\circ} \mathrm{C}, 2{ }^{\circ} \mathrm{C} / \mathrm{min}, 240 \mathrm{~min}$, as the biomass-to-water ratio increases from 1:10 to 1:20.

Author Contributions: The individual contributions of all the co-authors are provided as follows: C.d.M.S.d.S. contributed to formal analysis and writing-original draft preparation; D.A.R.d.C. contributed to formal analysis and writing-original draft preparation; M.C.S. contributed to formal analysis and software; H.d.S.A. contributed to formal analysis, software, and visualization; U.L. contributed to the investigation and validation; M.S. contributed to the investigation and methodology; T.H. contributed to resources and project administration; and N.T.M. contributed with supervision, 
conceptualization, and data curation. All authors have read and agreed to the published version of the manuscript.

Funding: This research was partially funded by CNPq-Brazil, grant number: 207325/2014-6.

Acknowledgments: We would like to acknowledge the Department of Postharvest Technology at Leibnitz-Institüt für Agrartechnik Potsdam-Bornin e.V for the opportunity to research at the Laboratory of Biochar, as well as for providing all the technical support (administrative, infrastructure, analytics) and materials to develop this research.

Conflicts of Interest: The authors declare no conflict of interest.

\section{References}

1. $\quad$ Lindolfo, M.M.; De Matos, G.S.B.; Pereira, W.V.D.S.; Fernandes, A.R. Productivity and nutrition of fertigated açaí palms according to boron fertilization. Rev. Bras. Frutic. 2020, 42, e601. [CrossRef]

2. Heinrich, M.; Dhanji, T.; Casselman, I. Açai (Euterpe oleracea. Mart.)—A phytochemical and pharmacologicalassessment of the species' health claims. Phytochem. Lett. 2011, 4, 10-21. [CrossRef]

3. Sabbe, S.; Verbeke, W.; Deliza, R.; Matta, V.; van Damme, P. Effect of a health claim and personal characteristics on consumer acceptance offruit juices with different concentrations of açaí (Euterpe oleracea Mart.). Appetite 2009, 53, 84-92. [CrossRef]

4. Del Pozo-Insfran, D.; Del Pozo-Insfran, D.; Brenes, C.H.; Brenes, C.H.; Talcott, S.T.; Talcott, S.T. Phytochemical Composition and Pigment Stability of Açai (Euterpe oleracea Mart.). J. Agric. Food Chem. 2004, 52, 1539-1545. [CrossRef]

5. Pessoa, J.D.C.; Silva, P.V.D.S.E. Effect of temperature and storage on açaí (Euterpe oleracea) fruit water uptake: Simulation of fruit transportation and pre-processing. Fruits 2007, 62, 295-302. [CrossRef]

6. Pompeu, D.; da Silva, E.M.; Rogez, H. Optimisation of the solvent extraction of phenolic antioxidants from fruits of Euterpe oleracea using Response Surface Methodology. Bioresour. Technol. 2009, 100, 6076-6082. [CrossRef] [PubMed]

7. Tavares, F.F.D.; de Almeida, M.D.C.; da Silva, J.A.P.; Araújo, L.L.; Cardozo, N.S.M.; Santana, R.M.C. Thermal treatment of açaí (Euterpe oleracea) fiber for composite reinforcement. Polímeros 2020, 30, e2020003. [CrossRef]

8. Bufalino, L.; Guimaraes, A.A.; de Silva, B.M.; de Souza, R.L.F.; de Melo, I.C.N.A.; de Oliveira, D.N.P.S.; Trugilho, P.F. Local variability of yield and physical properties of açaí waste and improvement of its energetic attributes by separation of lignocellulosic fibers and seeds. J. Renew. Sustain. Energy 2018, 10, 053102. [CrossRef]

9. De Lima, A.C.P.; Bastos, D.L.R.; Camarena, M.A.; Bon, E.P.S.; Cammarota, M.C.; Teixeira, R.S.S.; Gutarra, M.L.E. Physicochemical characterization of residual biomass (seed and fiber) from açaí (Euterpe oleracea) processing and assessment of the potential for energy production and bioproducts. Biomass Convers. Biorefin. 2019, 11, 925-935. [CrossRef]

10. Pessoa, J.D.C.; Arduin, M.; Martins, M.A.; De Carvalho, J.E.U. Characterization of açaí (E. oleracea) fruits and its processing residues. Braz. Arch. Biol. Technol. 2010, 53, 1451-1460. [CrossRef]

11. Barbosa, A.D.M.; Rebelo, V.S.M.; Martorano, L.G.; Giacon, V.M. Caracterização de partículas de açaí visando seu potencial uso na construção civil. Matéria 2019, 24. [CrossRef]

12. De Castro, D.A.R.; Ribeiro, H.J.D.S.; Ferreira, C.C.; Cordeiro, M.D.A.; Guerreiro, L.H.H.; Pereira, A.M.; dos Santos, W.; Santos, M.C.; De Carvalho, F.B.; Silva, J.O.C., Jr.; et al. Fractional Distillation of Bio-Oil Produced by Pyrolysis of Açaí (Euterpe oleracea) Seeds. Fractionation 2019. [CrossRef]

13. Li, L.; Flora, J.R.; Caicedo, J.M.; Berge, N.D. Investigating the role of feedstock properties and process con-ditions on products formed during the hydrothermal carbonization of organics using regression techniques. Bioresour. Technol. 2015, 187, 263-274. [CrossRef]

14. Machado, N.; de Castro, D.; Santos, M.; Araújo, M.; Lüder, U.; Herklotz, L.; Werner, M.; Mumme, J.; Hoffmann, T. Process analysis of hydrothermal carbonization of corn Stover with subcritical H2O. J. Supercrit. Fluids 2018, 136, 110-122. [CrossRef]

15. Möller, M.; Nilges, P.; Harnisch, F.; Schröder, U. Subcritical Water as Reaction Environment: Fundamentals of Hydrothermal Biomass Transformation. ChemSusChem 2011, 4, 566-579. [CrossRef]

16. Falco, C.; Baccile, N.; Titirici, M. Morphological and structural differences between glucose, cellulose and lignocellulosic biomass derived hydrothermal carbons. Green Chem. 2011, 13, 3273-3281. [CrossRef]

17. Liu, Z.; Balasubramanian, R. Hydrothermal carbonization of waste biomass for energy generation. Procedia Environ. Sci. 2012, 16, 159-166. [CrossRef]

18. Hoekman, S.K.; Broch, A.; Robbins, C.; Zielinska, B.; Felix, L. Hydrothermal carbonization (HTC) of selected woody and herbaceous biomass feedstocks. Biomass Convers. Biorefin. 2012, 3, 113-126. [CrossRef]

19. Guo, S.; Dong, X.; Wu, T.; Zhu, C. Influence of reaction conditions and feedstock on hydrochar properties. Energy Convers. Manag. 2016, 123, 95-103. [CrossRef]

20. Teri, G.; Luo, L.; Savage, P. Hydrothermal Treatment of Protein, Polysaccharide, and Lipids Alone and in Mixtures. Energy Fuels 2014, 28, 7501-7509. [CrossRef]

21. Borrero-López, A.M.; Masson, E.; Celzard, A.; Fierro, V. Modelling the reactions of cellulose, hemicellulose and lignin submitted to hydrothermal treatment. Ind. Crop. Prod. 2018, 124, 919-930. [CrossRef] 
22. Zhang, Y.; Hou, W.; Guo, H.; Shi, S.; Dai, J. Preparation and Characterization of Carbon Microspheres From Waste Cotton Textiles By Hydrothermal Carbonization. J. Renew. Mater. 2019, 7, 1309-1319. [CrossRef]

23. Öztürk, I.; Irmak, S.; Hesenov, A.; Erbatur, O. Hydrolysis of kenaf (Hibiscus cannabinus L.) stems by catalytical thermal treatment in subcritical water. Biomass Bioenergy 2010, 34, 1578-1585. [CrossRef]

24. Román, S.; Nabais, J.M.V.; Laginhas, C.; Ledesma, B.; González, J.F. Hydrothermal carbonization as an effective way of densi-fying the energy content of biomass. Fuel Process. Technol. 2012, 103, 78-83. [CrossRef]

25. Sermyagina, E.; Saari, J.; Kaikko, J.; Vakkilainen, E. Hydrothermal carbonization of coniferous biomass: Effect of process parameters on mass and energy yields. J. Anal. Appl. Pyrolysis 2015, 113, 551-556. [CrossRef]

26. Sabio, E.; Álvarez-Murillo, A.; Román, S.; Ledesma, B. Conversion of tomato-peel waste into solid fuel by hydrothermal car-bonization: Influence of the processing variables. Waste Manag. 2016, 47, 122-132. [CrossRef] [PubMed]

27. Álvarez-Murillo, A.; Roman, S.; Ledesma, B.; Sabio, E. Study of variables in energy densification of olive stone by hydrothermal carbonization. J. Anal. Appl. Pyrolysis 2015, 113, 307-314. [CrossRef]

28. Heilmann, S.M.; Davis, H.T.; Jader, L.R.; Lefebvre, P.A.; Sadowsky, M.; Schendel, F.J.; Von Keitz, M.G.; Valentas, K.J. Hydrothermal carbonization of microalgae. Biomass Bioenergy 2010, 34, 875-882. [CrossRef]

29. Oktaviananda, C.; Rahmawati, R.F.; Prasetya, A.; Purnomo, C.W.; Yuliansyah, A.T.; Cahyono, R.B. Effect of temperature and biomass-water ratio to yield and product characteristics of hydrothermal treatment of biomass. In Proceedings of the AIP Conference Proceedings, Bydgoszcz, Poland, 9-11 May 2018; AIP Publishing Center: Yogyakarta, Indonesia, 2017; p. 020029. [CrossRef]

30. Putra, H.; Damanhuri, E.; Dewi, K.; Pasek, A.D. Hydrothermal carbonization of biomass waste under low temperature condition. In Proceedings of the 2nd International Conference on Engineering and Technology for Sustainable Development (ICET4SD 2017), Yogyakarta, Indonesia, 13-14 September 2017; Volume 154, p. 01025. [CrossRef]

31. Castello, D.; Kruse, A.; Fiori, L. Biomass gasification in supercritical and subcritical water: The effect of the reactor material. Chem. Eng. J. 2013, 228, 535-544. [CrossRef]

32. Lucian, M.; Fiori, L. Hydrothermal Carbonization of Waste Biomass: Process Design, Modeling, Energy Efficiency and Cost Analysis. Energies 2017, 10, 211. [CrossRef]

33. Axel, F.; Felix, R.; Andrea, K. Experimental comparison of hydrothermal and vapothermal carbonization. Fuel Process. Technol. 2013, 115, 261-269.

34. Zhang, B.; Huang, H.J.; Ramaswamy, S. Reaction kinetics of the hydrothermal treatment of lignin. Appl. Biochem. Biotechnol. 2008, 147, 119-131. [CrossRef]

35. Li, L.; Diederick, R.; Flora, J.R.; Berge, N.D. Hydrothermal carbonization of food waste and associated packaging materials for energy source generation. Waste Manag. 2013, 33, 2478-2492. [CrossRef]

36. Funke, A.; Ziegler, F. Hydrothermal carbonization of biomass: A summary and discussion of chemical mechanisms for process engineering. Biofuels Bioprod. Biorefin. 2010, 4, 160-177. [CrossRef]

37. Wannapeera, J.; Fungtammsan, B.; Worasuwannarak, N. Effects of temperature and holding time during tor-refaction on the pyrolysis behaviors of woody biomass. J. Anal. Appl. Pyrolysis 2011, 92, 99-105. [CrossRef]

38. Sevilla, M.; Fuertes, A.B. The production of carbon materials by hydrothermal carbonization of cellulose. Carbon 2009, 47, 2281-2289. [CrossRef]

39. Becker, R.; Dorgerloh, U.; Paulke, E.; Mumme, J.; Nehls, I. Hydrothermal Carbonization of Biomass: Major Organic Components of the Aqueous Phase. Chem. Eng. Technol. 2014, 37, 511-518. [CrossRef]

40. Reza, M.T.; Wirth, B.; Lueder, U.; Werner, M. Behavior of selected hydrolyzed and dehydrated products during hydrothermal carbonization of biomass. Bioresour. Technol. 2014, 169, 352-361. [CrossRef] [PubMed]

41. Becker, R.; Dorgerloh, U.; Helmis, M.; Mumme, J.; Diakité, M.; Nehls, I. Hydrothermally carbonized plant materials: Patterns of volatile organic compounds detected by gas chromatography. Bioresour. Technol. 2013, 130, 621-628. [CrossRef]

42. Jung, D.; Zimmermann, M.; Kruse, A. Hydrothermal Carbonization of Fructose: Growth Mechanism and Kinetic Model. ACS Sustain. Chem. Eng. 2018, 6, 13877-13887. [CrossRef]

43. Hoekman, S.K.; Broch, A.; Robbins, C. Hydrothermal Carbonization (HTC) of Lignocellulosic Biomass. Energy Fuels 2011, 25, 1802-1810. [CrossRef]

44. Poerschmann, J.; Weiner, B.; Koehler, R.; Kopinke, F.D. Hydrothermal Carbonization of Glucose, Fructose, and XyloseIdentification of Organic Products with Medium Molecular Masses. ACS Sustainable Chem. Eng. 2017, 5, 6420-6428. [CrossRef]

45. Kabyemela, B.M.; Takigawa, M.; Adschiri, T.; Malaluan, R.M.; Arai, K. Mechanism and Kinetics of Cellobiose Decomposition in Sub- and Supercritical Water. Ind. Eng. Chem. Res. 1998, 37, 357-361. [CrossRef]

46. Román, S.; Libra, J.; Berge, N.; Sabio, E.; Ro, K.; Li, L.; Ledesma, B.; Álvarez, A.; Bae, S. Hydrothermal Carbonization: Modeling, Final Properties Design and Applications: A Review. Energies 2018, 11, 216. [CrossRef]

47. Oliveira, J.; Komesu, A.; Maciel Filho, R. Hydrothermal Pretreatment for Enhancing Enzymatic Hydrolysis of Seeds of Açaí (Euterpe oleracea) and Sugar Recovery. Chem. Eng. Trans. 2014, 37, 785-792.

48. Bauer, S.K.; Cheng, F.; Colosi, L.M. Evaluating the Impacts of ACP Management on the Energy Performance of Hydrothermal Liquefaction via Nutrient Recovery. Energies 2019, 12, 729. [CrossRef] 
49. Shah, A.; Toor, S.; Nielsen, A.; Pedersen, T.; Rosendahl, L. Bio-Crude Production through Recycling of Pretreated Aqueous Phase via Activated Carbon. Energies 2021, 14, 3488. [CrossRef]

50. Standards, T. Acid-Insoluble Lignin in Wood and Pulp Tappi Method T 222 Om-06; Tappi Press: Atlanta, GA, USA, 2006.

51. Buffiere, P.; Loisel, D.; Van Soest, P.J. Dosage des Fibres; Inra-Lbe Laboratoire De Biotechnologie De L'environnement: Narbonne, France, 2007; pp. 1-14. 